\title{
Shedding Light on Shadow Banking
}




\section{Shedding Light on Shadow Banking}

Artak Harutyunyan, Alexander Massara, Giovanni Ugazio,

Goran Amidzic, and Richard Walton 


\title{
IMF Working Paper
}

\author{
Statistics Department
}

Shedding Light on Shadow Banking

Prepared by Artak Harutyunyan, Alexander Massara, Giovanni Ugazio, Goran Amidzic, and Richard Walton ${ }^{1}$

Authorized for distribution by Luca Errico

January 2015

\section{This Working Paper should not be reported as representing the views of the IMF.} The views expressed in this Working Paper are those of the author(s) and do not necessarily represent those of the IMF or IMF policy. Working Papers describe research in progress by the author(s) and are published to elicit comments and to further debate.

\begin{abstract}
In this paper, we develop an alternative approach to estimate the size of the shadow banking system, using official data reported to the IMF complemented by other data sources. We base our alternative approach on the expansion of the noncore liabilities concept developed in recent literature to encompass all noncore liabilities of both bank and nonbank financial institutions. As opposed to existing measures of shadow banking, our newly developed measures capture nontraditional funding raised by traditional banks. We apply the new approach to 26 jurisdictions and analyze the results over a twelve-year span. We find that noncore liabilities are procyclical and display more volatility than core liabilities for most jurisdictions in the sample. We also compare our measures to existing measures, such as the measure developed by the Financial Stability Board. Our approach can be replicated over time using internationally-comparable data and thus may serve as an operational tool for IMF surveillance and policy analysis.
\end{abstract}

JEL Classification Numbers: E51, F34, G01, G21, G23

Keywords: shadow banking, noncore liabilities, financial intermediation

Corresponding Authors’ E-Mail Addresses: aharutyunyan@imf.org; amassara@imf.org

\footnotetext{
${ }^{1}$ We are grateful to Luca Errico for his encouragement and guidance throughout this project. We would like to thank Nicolas Arregui, Johannes Ehrentraud, Gaston Gelos, Robert Heath, and Nico Valckx for helpful comments. Suggestions from Ali Abbas, Tamim Bayoumi, Ashoka Bhatia, Sally Chen, Thomas Elkjaer, Michael Gorbanyov, Yinqui Li, Jose Carlos Moreno-Ramirez, Marshall Reinsdorf, and Mike Seiferling are gratefully acknowledged. We would also like to thank Luisa Menjivar, Pratibha Kumar, and Catherine Unbyul Cho for their help with the illustrations.
} 


\section{Contents}

Abstract

I. Introduction

II. Literature review

III. Shadow Banking as Nontraditional Financial Intermediation

A. Institutions.

B. Counterparts

C. Financial Instruments ...

IV. Source data and Country Sample

V. Discussion of Results

A. Size of Core and Noncore Liabilities ........................................................ 15

B. Growth rates and variability

C. Comparison with FSB estimates

VI. Data gaps

VII. Illustrative Analysis

VIII. Conclusions

\section{Tables}

Table 1. Availability of Data by Sector and Jurisdiction ..................................................14

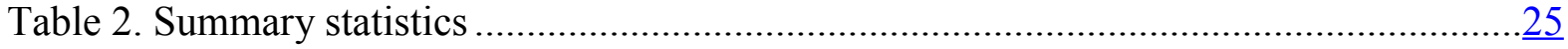

Table 3. Broad noncore liabilities, percent of GDP ...................................................... 35

Table 4. Narrow noncore liabilities, percent of GDP …..................................................

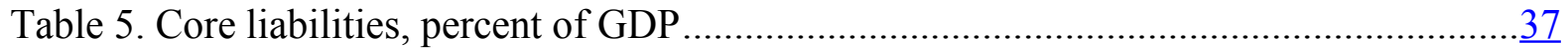

Table 6. Broad noncore liabilities (USD billion) .......................................................... $\underline{38}$

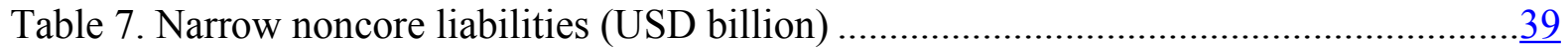

Table 8. Core liabilities (USD billion) ..................................................................... 40

\section{Figures}

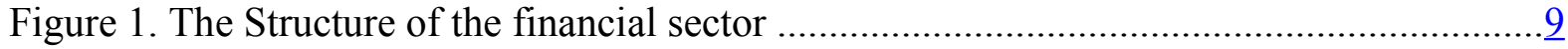

Figure 2. Components of Broad and Narrow Noncore Liabilities .....................................12

Figure 3. Credit Intermediation through Traditional and Shadow Banking .........................13

Figure 4. Evolution of the Shadow Banking System in Selected Jurisdictions ......................15

Figure 5. Core and noncore liabilities (percent of GDP) ...............................................17

Figure 6. United States: Instrument Composition of Noncore Liabilities ............................18

Figure 7. Euro Area: Instrument Composition of Noncore Liabilities ...............................19

Figure 8. Core and Noncore Liabilities in Europe in 2008:Q3 and 2013:Q4 .......................20 
Figure 9. Quarterly Changes of Core (Stripes) and Noncore (Solid) Liabilities ......................22

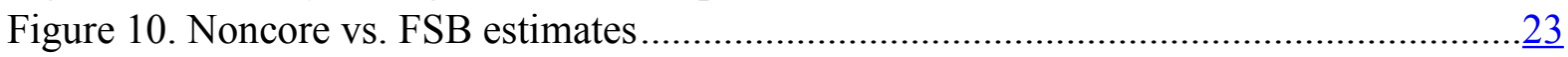

Figure 11. Growth of Noncore Ratio Indicator and GDP for the US and the Euro Area .........26
Appendices
I. Comparison of Selected SBS Measurement Methodologies
.$\underline{29}$
II. Compilation Details for Individual Countries .................................................................

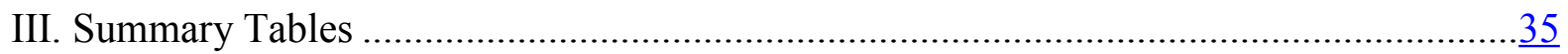


"A further worry is the migration of new market and liquidity risks to the "shadows" of the financial world. This is part of the less-regulated, nonbank sector, which is growing rapidly in some countries. [...] Of course, nonbank activities can complement the banking sector in financing the economy in important ways. Yet, the opaqueness of these activities warrants heightened vigilance...."2

Christine Lagarde, Managing Director of the IMF

\section{INTRODUCTION}

Following the global financial crisis, researchers and policy makers focused on developing early warning indicators of risk buildup in the financial system and possible spillovers to other macroeconomic sectors. A central aspect of these efforts has been a closer examination of the less traditional financial intermediation activities, with a focus on the funding sources of financial intermediaries.

Traditionally, banks raise funds by accepting deposits from households and nonfinancial corporations and then use the deposits to finance their lending activities. These deposits can be viewed as the "core" funding of the financial system. During periods of rapid economic growth, core funding is likely to be insufficient to finance the growth in credit demand. As a result, nontraditional ("noncore") sources are tapped by banks and nonbank financial institutions alike. In this vein, the state of the business cycle is often reflected in the composition of financial sector funding sources (i.e., noncore liabilities correlate positively with the business cycle). ${ }^{3}$

Recent literature suggests that the size, source, and composition of noncore liabilities provide useful insights into the financial system's health and the potential for spillovers to the real economy. ${ }^{4}$ To date, however, no harmonized data exist on noncore liabilities, constraining empirical analysis. Furthermore, most of the analysis of nontraditional funding sources has so far focused on nonbank financial institutions, associating these with the so-called shadow banking system (SBS). Several attempts at measuring the SBS as nonbank financial intermediation have been made using various SBS definitions. ${ }^{5}$ These approaches, however, miss significant

\footnotetext{
${ }^{2}$ The Challenge Facing the Global Economy: New Momentum to Overcome a New Mediocre, remarks by Christine Lagarde, Managing Director, International Monetary Fund, Georgetown University, School of Foreign Service, October 2, 2014.

${ }^{3}$ See Shin and Shin, 2010, and Figure 11.

${ }^{4}$ See Chen et al., 2012.

${ }^{5}$ Appendix I provides a summary of these definitions. In particular, see Financial Stability Board, 2013; Organization for Economic Cooperation and Development (OECD), 2012; Bakk-Simon et al., 2012; Pozsar, Adrian, Ashcraft and Boesky, 2010; Claessens et al., 2012.
} 
nontraditional banking activities carried out by the banks themselves, thus leading to an incomplete picture of the SBS and of the potential vulnerabilities associated with it.

Against this background, we propose an alternative approach to estimate the size of the SBS, based on the expansion of the noncore liabilities concept developed in recent literature (Shin and Shin, 2010), to encompass all noncore liabilities of both banks and nonbank financial

institutions. The more comprehensive concept of noncore liabilities produces a more analytically relevant measure of those financial (credit) intermediation activities comprising the SBS, both across countries and over time.

In our proposed approach, ${ }^{6}$ overall credit intermediation is viewed as a chain of activities between financial institutions and the other institutional sectors using a variety of financial instruments, consisting of both traditional and shadow banking activities. We consider shadow banking to be all intermediation that can be characterized as nontraditional from the point of view of the funding source. To this end, we subdivide the non-equity funding of financial intermediation into core (traditional) and noncore (nontraditional) liabilities. In this framework, core liabilities include bank deposits mainly from nonfinancial corporations and households, while noncore liabilities include all the remaining funding sources, particularly market funding.

To apply our methodology, we used data officially reported to the $\mathrm{IMF}^{7}$ complemented by alternative data sources, to construct and analyze measures of core and noncore liabilities (narrow and broad) for 26 jurisdictions. Our findings indicate that, compared to core liabilities, average growth rates for both noncore liabilities measures had greater variation during the period Q4:2001 -Q4:2013. Further, our results show that in many of the jurisdictions considered (including the US, euro area, and Japan) noncore liabilities are procyclical. These findings are consistent with some of the main findings in Shin and Shin (2010).

\section{LITERATURE REVIEW}

The concept of noncore liabilities as a nontraditional source of funding adopted in our paper builds on Shin and Shin (2010). In their work, the authors lay out the conceptual distinction between core and noncore liabilities of the banking sector as different means of funding. Their paper discusses how these two types of liabilities relate to monetary and credit aggregates and, using monetary data for the Republic of Korea, finds that noncore liabilities increase the vulnerability of the banking sector to sharp exchange rate depreciation and to increases in borrowing spreads.

\footnotetext{
${ }^{6}$ See Section III of this paper for a fuller description and schematic presentation of this approach.

${ }^{7}$ Monetary and financial statistics reported to the IMF via the Standardized Report Forms (SRFs).
} 
Following Shin and Shin (2010), several papers have sought to apply the core-noncore framework to construct indicators of credit cycles and to derive macroprudential policy conclusions. ${ }^{8}$ For example, Chen et al. (2012), in the context of measuring global liquidity, suggest that monitoring developments in noncore (or shadow banking) funding can provide useful insights on financial sector developments and their implications for the real economy. Hahm et al. (2011a) explain how lending booms coincide with shifts from core to noncore liabilities.

In another paper, Hahm et al. (2012) build a model of credit supply and show that banks turn to noncore liabilities when they need to finance a rapid expansion of credit. The main intuition of this paper is that core liabilities (traditional bank deposits) are "sticky" and do not move as procyclically and, for this reason, do not keep up with the expansion of the balance sheet during a credit boom. Along these lines, Errico et al. (2014) discuss the procyclicality of noncore liabilities introducing a global flow of funds framework to map the SBS in the United States.

Furthermore, several papers, such as Shin (2011) and Adrian and Shin (2009, 2012), have successfully applied the Shin and Shin (2010) framework to empirical studies of credit booms, financial instability and financial crisis. The key concept to study these scenarios is procyclical balance sheet leverage of the banking system. Finally, Hahm et al. (2011b) analyze the link between various definitions of noncore bank liabilities and different measures of crises and find that noncore liabilities have predictive power for both currency and credit crises.

Although our approach focuses on noncore liabilities in measuring and analyzing shadow banking, it relates to the stream of literature interpreting shadow banking from the perspective of nontraditional credit intermediation. The initial analytical works on the SBS were prepared by Pozsar (2008) and Adrian and Shin (2009), and focused on the role of the SBS in undermining financial stability in light of the global financial crisis. These papers identify the SBS from an institutional perspective: broadly speaking, a shadow bank is an institution outside the banking system's regulatory framework (i.e., for most countries all banks are excluded, regardless of their funding structure) which nonetheless provides financial intermediation services similar to those of banks. ${ }^{9}$ This is the framework followed by the Financial Stability Board (FSB) to estimate shadow banking, and applied to the case of the euro area by Bakk-Simon et al. (2012). In this paper, Bakk-Simon et al. build a definition of shadow banking starting from nontraditional credit intermediation. However, due to data limitations, they construct a proxy for the SBS using total assets of the nonbank financial sector, excluding non-money market (MMF) investment funds,

\footnotetext{
${ }^{8}$ Although many studies build on the Shin and Shin (2010) framework, earlier papers, such as Schularick and Taylor (2009), already discussed the link between credit dynamics and liability composition.

${ }^{9}$ For an extensive review of the existing literature on the SBS, institutions involved in SBS activities, their regulatory framework and impact of recent reform efforts on the SBS, see Pozsar, Adrian, Ashcraft, and Boesky (2010), and Adrian and Ashcraft (2012).
} 
insurance corporations, and pension funds. The overlap of our approach with this stream of literature lies in the measurement of financial intermediation outside traditional banking activities.

\section{SHADOW BANKING AS NONTRADITIONAL FINANCIAL INTERMEDIATION}

In our approach, we identify shadow banking as nontraditional financial intermediation, which is determined by the funding source used by financial intermediaries to finance a portion of their assets. In this section, we provide all the relevant definitions concerning institutions and instruments belonging to the SBS, as well as two measures of the SBS. In addition, we translate these definitions into their direct application to make our framework operational and link it to specific types of financial institutions and instruments.

Before delving into the definitions and the application of the framework, it is important to note that the regulatory aspect is not an explicit defining characteristic of shadow banking in our methodology. This is due to the fact that both banks and nonbanks may be involved in the SBS, irrespective of the regulatory regime. However, given that core funding of the financial system consists of (insured) bank deposits, the regulatory aspect at the activity level applies implicitly. ${ }^{10}$

Nontraditional funding sources (noncore liabilities) in our approach are thus defined based on the following three dimensions: (i) the types of financial institutions that are issuers of noncore liabilities; (ii) the holders of noncore liabilities (counterparts); and (iii) the financial instruments that are the components of noncore liabilities.

\section{A. Institutions}

We consider that all financial institutions involved in the credit intermediation chain may potentially issue SBS-like liabilities. This is consistent with some recent literature (e.g., Shiller (2012)) arguing that, at the level of individual institutions, banks' involvement in SBS activities can be significant. To better illustrate the rationale for the inclusion of banks as potential issuers of SBS-like liabilities, consider the case of a bank that securitizes a portion of its balance sheet. If the transaction is carried out by establishing a special purpose vehicle (i.e., the transaction is mediated by a nonbank financial institution), the resulting securities would be captured by existing methodologies attempting to measure the SBS. If, on the other hand, the bank were to securitize directly (on-balance sheet securitization), ${ }^{11}$ the resulting securities (including covered bonds) would not be captured by those same methodologies, but would be captured in our measure.

\footnotetext{
${ }^{10}$ Chapter 2 of the October 2014 Global Financial Stability Report discusses the regulatory aspect of SBS activities in some detail.

${ }^{11}$ For the definition of securitization see paragraphs 4.4-4.10, Handbook on Securities Statistics, Part 1.
} 
While this concept is relatively straightforward, its application is less so because of the very heterogeneous nature (across countries and sectors) of some nonbank financial intermediaries. For the purpose of our exercise, we include, as providers of financial intermediation services, institutions that belong to both the other depository corporations (ODCs) and other financial corporations (OFCs) sectors, ${ }^{12}$ as defined in the IMF's Monetary and Financial Statistics Manual (MFSM). ${ }^{13}$ In particular, we include as issuers of SBS-like liabilities: (i) banks; (ii) money market funds (MMFs); and (iii) all nonbank financial institutions, except non-MMF investment funds (IFs), insurance corporations and pension funds (ICPFs), and financial auxiliaries (Figure 1). This last group of institutions will be referred to as other financial intermediaries (OFIs) henceforth. Depending on data availability, the OFI category consists of specific institutions for some countries (e.g., financial vehicle corporations), while for others, it is calculated as a residual once IF and ICPF liabilities are excluded from total assets of nonbank financial institutions.

The rationale for excluding IFs and ICPFs from our shadow banking measure lies in the very specific nature of the financial services they provide, which generally does not involve credit intermediation. The exclusion of ICPF liabilities from shadow banking is widely accepted. Concerning IFs, studies have often excluded them (Bakk-Simon and others 2012; Adrian and Ashcraft 2012), but we acknowledge that other studies have argued for their inclusion as issuers of SBS-like liabilities. ${ }^{14}$ Both approaches have their merits. Nonetheless, we maintain that the business model of most IFs consists of investing assets on behalf of their clients, who bear the risk of loss. In other words, IFs generally do not participate directly in credit provision and maturity transformation. Finally, while the IF subsector may include some types of institutions that are potential issuers of SBS-like liabilities, the lack of data granularity (e.g., detailed balance sheets by type of fund) prevents a more in-depth assessment and their inclusion in our SBS measure.

\footnotetext{
${ }^{12}$ Three major groups of OFCs can be identified: insurance corporations and pension funds, other financial intermediaries (OFIs), and financial auxiliaries.

${ }^{13}$ The MFSM and its companion Monetary and Financial Statistics Compilation Guide are being updated and will be merged in one single document. The draft of the new Monetary and Financial Statistics Manual and Compilation Guide (MFSMCG) is currently posted on the IMF's website for public comment at http://www.imf.org/external/data.htm\#guide.

${ }^{14}$ For example, see FSB (2014).
} 


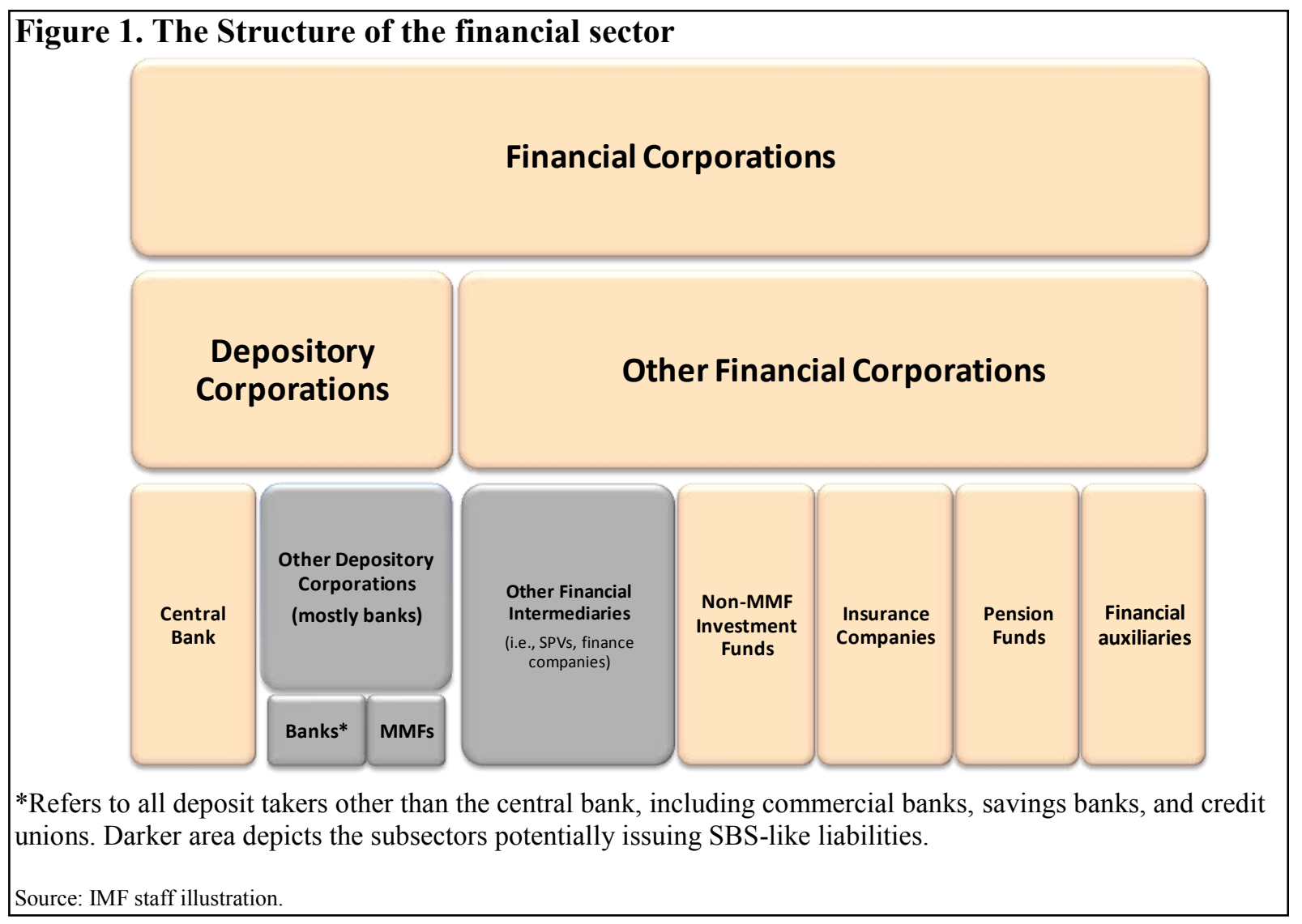

\section{B. Counterparts}

After defining the issuers of SBS-like liabilities, we move to their holders and introduce the notion of "ultimate domestic creditors," as in Shin and Shin 2010. These are basically the domestic fund providers to financial intermediaries and include (i) IFs, ICPFs, and financial auxiliaries, (ii) nonfinancial corporations, (iii) households, ${ }^{15}$ and (iv) state and local government. $^{16}$

The counterparts of the funding raised through the issuance of core or noncore liabilities may thus be divided into three main categories (see Shin and Shin 2010): (i) ultimate domestic creditors; (ii) other resident creditors that issue SBS-like liabilities (banks, MMFs, and OFIs); and (iii) nonresident creditors.

\footnotetext{
${ }^{15}$ Including nonprofit institutions serving households (NPISH)

${ }^{16}$ Liabilities to the central government and the central bank are not part of either core or noncore liabilities. This is due to the special nature of their deposits and loans within the financial system, which are intended for policy purposes. This excludes the central government and the central bank from being part of the "ultimate domestic creditors."
} 


\section{Financial Instruments}

Finally, we divide the non-equity funding sources used by the issuers of SBS-like liabilities into core and noncore liabilities. ${ }^{17}$ Core liabilities can be viewed as representing the standard funding supporting the financial intermediation function of the banking system. These liabilities can be defined as the funding that the intermediaries traditionally draw on, consisting of regular deposits from ultimate domestic creditors. In our framework, banks are the issuers of these types of liabilities.

We consider noncore liabilities (or SBS-like liabilities) to be all sources of funding for financial intermediaries that lie outside the core definition. For the purpose of this paper, noncore funds are raised by issuing debt securities, loans, MMF shares, and by accepting certain types of restricted deposits, which due to their nature do not qualify as core funding (e.g., compulsory savings deposits). In addition, all funding obtained from nonresidents is also included in noncore liabilities. ${ }^{18}$ As opposed to core liabilities, which are only issued by banks, noncore liabilities may be issued by banks, MMFs, and OFIs.

The noncore liabilities measure can be constructed either gross (henceforth, broad measure) or net (henceforth, narrow measure) of intra-SBS balance sheet positions, that is, to include (broad) or exclude (narrow) intra-SBS positions whereby an asset of one financial corporation represents the liability (funding source) of another. For instance, consider a bank that holds as an asset a debt security issued by a domestic securitization vehicle. This debt security would be part of the broad measure of noncore liabilities, but would be excluded from the narrow measure.

The choice of instruments for noncore liabilities to include all bank funding besides (most) deposits is admittedly very extensive, compared with those used by most other attempts at measuring the SBS cited in the literature (see Appendix I). The specific choice of instruments is partially affected by data granularity, and, in principle, can be debated and further improved both from the conceptual and data availability perspectives.

In particular, among the liabilities of banks and MMFs, some considerations are warranted for debt securities and MMF shares issued. Some categories of debt securities, such as certificates of deposits and long term bonds, represent a traditional and stable funding base for banks, which could in principle qualify them as part of core funding. However, such granularity is not available in the source data (SRFs) used; therefore all debt securities are included in noncore

\footnotetext{
${ }^{17}$ Liabilities in the form of derivatives and unclassified liabilities are excluded from our analysis as these are not considered to be core or noncore sources of funding. Own funds (liability equity) are also excluded.

${ }^{18}$ The inclusion of liabilities to nonresidents into the noncore category follows the framework laid out in Shin and Shin (2010). These positions are viewed as nontraditional and less stable financing sources than regular deposits from ultimate domestic creditors.
} 
liabilities. If and when more granularity for different types of debt securities becomes available, an improved measure could be constructed.

Turning to MMF shares, two main features need to be considered. On one hand, due to their nature, MMF shares may be a close substitute for regular bank deposits; therefore MMF shares could be considered as part of core funding. On the other hand, we argue that MMF shares are not a stable source of funding for the SBS, as, unlike traditional deposits, they are subject to investor confidence and market sentiment, suggesting that MMF issuance behaves differently relative to stable core liabilities. For this reason, consistent with most other SBS measures, we include MMF shares issued as part of noncore funding.

In our framework, interbank borrowing (including borrowing from the central bank) in the form of either loans received or deposits is excluded from both the core and the noncore liabilities measures. The rationale for this lies in the nature of these operations, which with well functioning markets are generally not meant to form part of the financial intermediaries' funding base for credit intermediation. All other interbank positions (e.g., debt securities) are included in the broad noncore liabilities measure.

Figure 2 summarizes the components of the broad and narrow definitions of noncore liabilities. The broad measure of noncore liabilities, which includes intra-SBS positions, is most useful for financial stability assessment purposes, as it reflects all exposures of the SBS, including its level of interconnectedness within the SBS. The narrow measure of noncore liabilities reflects the net exposure of the SBS to macroeconomic sectors outside the SBS. The broad and narrow measures complement each other and can be interpreted as the upper and lower bounds, respectively, of the estimated size and interconnectedness of the SBS in a given country or country grouping. 


\section{Figure 2. Components of Broad and Narrow Noncore Liabilities}

Box A shows the instruments included in noncore liabilities, which are labeled "SBS-like instruments," and the issuing institutions of such liabilities. The distinction between the broad and narrow measures of noncore liabilities lies in the counterparts. The narrow measure, shown in Box B, includes ultimate domestic creditors and nonresidents as counterparts. The broad measure, shown in box $\mathrm{C}$, includes all liabilities included in the narrow measures plus intra-SBS positions i.e., those held by banks, MMFs, and OFIs.

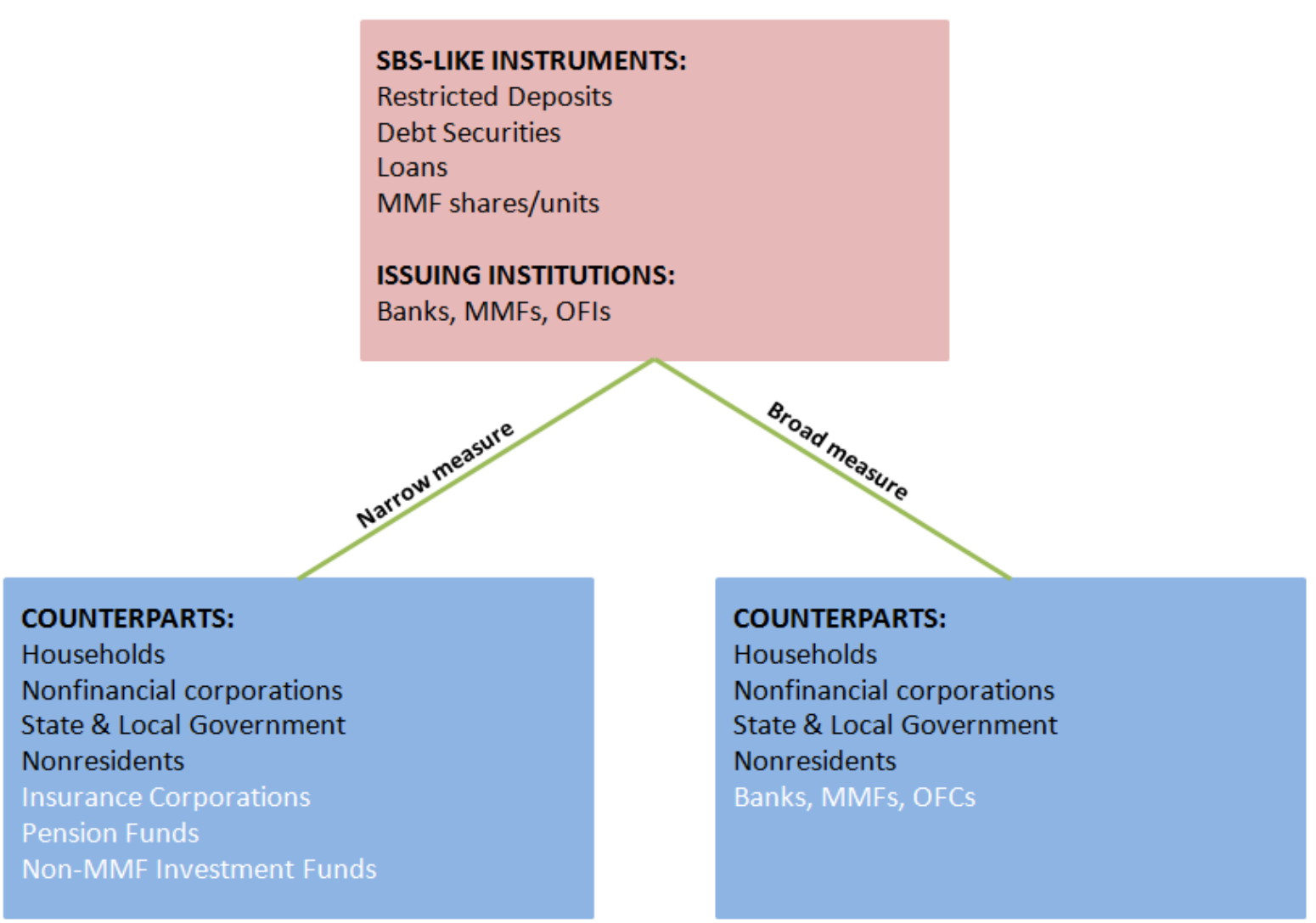

Box A shows the issuers and types of instruments included in both the narrow and broad measures of noncore liabilities. The distinction between the two measures is derived from the counterparts, shown in Boxes B and C in white color. Both measures include ultimate creditors and nonresidents as counterparts. The narrow measure includes only a subset of the OFC sector, while the broad measure includes all OFCs and all ODCs.

Source: IMF staff illustration.

Figure 3 provides a schematic representation of the credit intermediation network and the activities of the SBS within the network. The initial funding sources of core and noncore liabilities issued by financial intermediaries are the ultimate domestic creditors and nonresidents. The funds entering the financial system can take the form of either core or noncore liabilities. Figure 3 shows that banks issue both core (lightly shaded region) and noncore liabilities (shaded in dark), while MMFs and OFIs issue only noncore liabilities. The funding is used to support lending directed both among financial intermediaries and outside the system. The dashed line 
represents intra-SBS activities. The narrow noncore liabilities measure, represented by the solid blue line, excludes intra-SBS positions, so that the (re)investment of funds within the SBS does not affect the narrow measure. The sum of the intra-SBS and narrow noncore liabilities lines denotes the broad noncore liabilities measure.

\section{Figure 3. Credit Intermediation through Traditional and Shadow Banking}

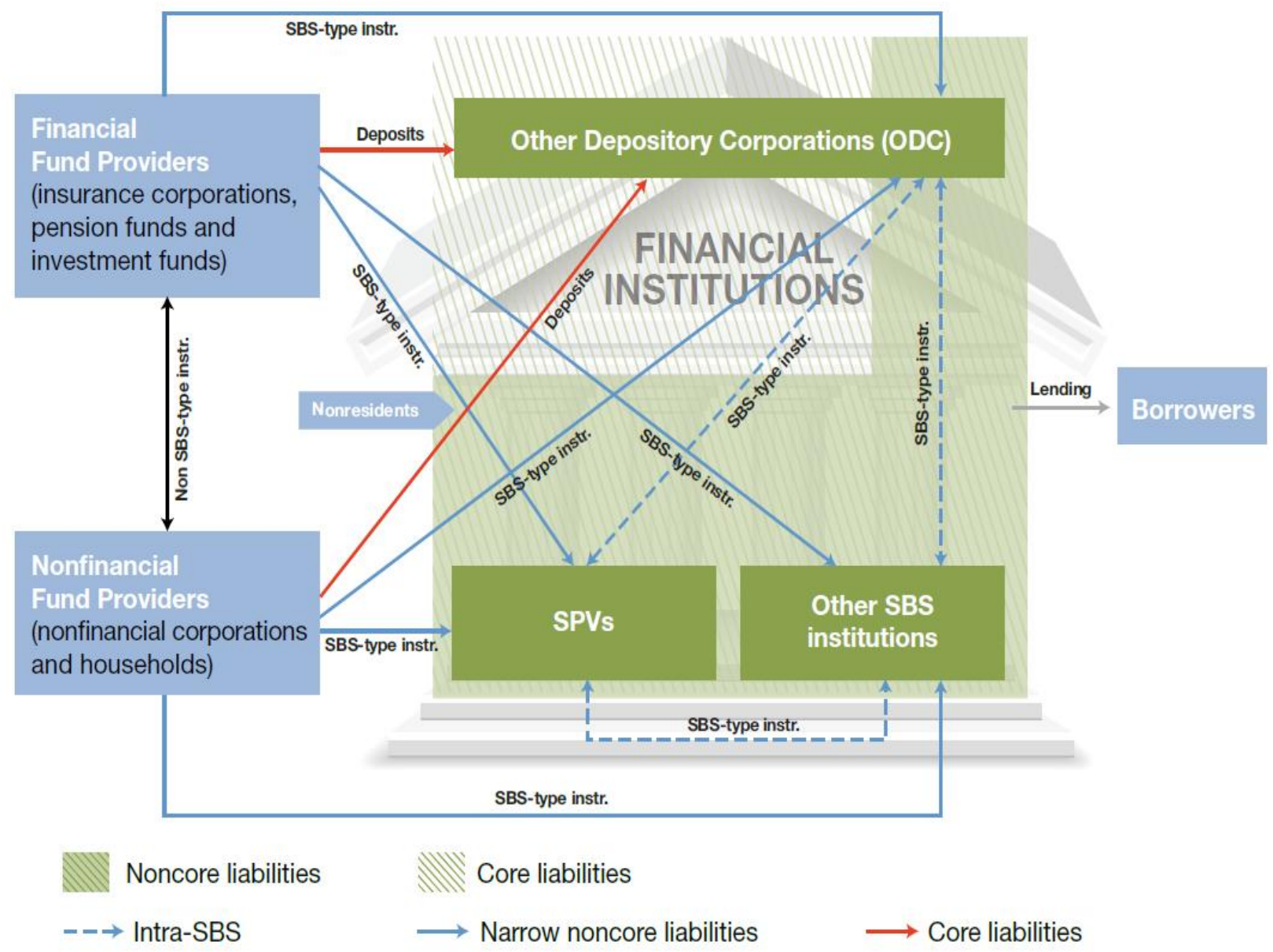

The figure depicts credit intermediation conducted through traditional and shadow banking. Unlike other measures of shadow banking, this approach shows how nontraditional financial intermediation is conducted by both ODCs (banks and MMFs) and OFIs.

Source: IMF staff illustration. 


\section{SOURCE DATA AND COUNTRY SAMPLE}

Monetary statistics (SRFs) data available at the IMF supplemented by other data (see Appendix II) have been used to compute core and noncore liabilities (broad and narrow) for 26 countries. The euro area and 17 of its members ${ }^{19}$ form the majority of the country sample. Of the remaining countries, there are three major Asian economies (Japan, Korea, and Thailand), as well as Mexico, South Africa, Turkey, the United States, and the United Kingdom. ${ }^{20}$

For most countries in the sample, we developed a quarterly dataset covering Q4:2001-Q4:2013. Most of the data needed could be sourced from the IMF's SRFs. The SRFs provide the required breakdowns by instrument and counterpart sector for assets and liabilities of these financial subsectors based on the MFSM. The SRFs enable cross-country comparability and have the benefit of being officially reported data, as noted previously. Where data gaps existed, ad hoc data were sourced from official websites or through bilateral contacts with the countries concerned. ${ }^{21}$ Table 1 summarizes the availability of data required to compile our measures of core and noncore liabilities for each country in our sample.

Table 1. Availability of Data by Sector and Jurisdiction

\begin{tabular}{|c|c|c|c|c|c|c|}
\hline & \multicolumn{2}{|c|}{$\mathrm{ODCs}$} & \multicolumn{4}{|c|}{ OFCs } \\
\hline & Banks & $\mathrm{MMFs}$ & $\mathrm{OF}$ Is & IFs & ICPFs & Total \\
\hline $\begin{array}{l}\text { Euro area } \\
\text { (total and individual countries) }\end{array}$ & $\checkmark$ & $\checkmark$ & $\checkmark / x$ & $\checkmark$ & $\checkmark / x$ & $\checkmark / x$ \\
\hline Japan & $\checkmark$ & $\checkmark$ & $\checkmark / x$ & $\checkmark / x$ & $\sqrt{1 x}$ & $\checkmark$ \\
\hline Korea & $\checkmark$ & $\checkmark$ & $\checkmark / x$ & $\checkmark / x$ & $\checkmark / x$ & $\checkmark / x$ \\
\hline Mexico & $\checkmark$ & $\checkmark$ & $x$ & $x$ & $x$ & $\checkmark$ \\
\hline South Africa & $\checkmark$ & $\checkmark$ & $\checkmark$ & $\checkmark$ & $\checkmark$ & $\checkmark$ \\
\hline Thailand & $\checkmark$ & $\checkmark / x$ & $x$ & $x$ & $x$ & $\checkmark$ \\
\hline Turkey & $\checkmark$ & $\checkmark$ & $\checkmark / x$ & $x$ & $\checkmark / x$ & $\checkmark$ \\
\hline United Kingdom & $\checkmark / x$ & $\checkmark / x$ & $x$ & $x$ & $x$ & $\checkmark / x$ \\
\hline United States & $\checkmark$ & $\checkmark$ & $\checkmark$ & $\checkmark$ & $\checkmark$ & $\checkmark$ \\
\hline
\end{tabular}

Instrument breadown, sectorization and frequency of source data:

\begin{tabular}{|c|l}
\hline$\checkmark$ & Full implementation of methodology. No estimation. \\
& Partial implementation of methodology. Some estimation, see Appendix II. \\
& No implementation of methodology. Full estimation, see Appendix II.
\end{tabular}

Dotted area depicts the subsectors is suing SBS-like liabilities

Source: IMF staff estimates.

\footnotetext{
${ }^{19}$ Latvia is not included in our sample.

${ }^{20}$ Only the broad measure of noncore liabilities was calculated for Mexico and Thailand.

${ }^{21}$ For example, the SRF for OFCs includes all OFCs and thus the data for IFs and ICPFs cannot be isolated.
} 


\section{Discussion OF RESUlts}

\section{A. Size of Core and Noncore Liabilities}

Figure 4 provides a snapshot of the evolution of the SBS, measured as broad noncore liabilities in percentage of GDP, in selected jurisdictions before, at the onset of, and after the global financial crisis. ${ }^{22}$ For example, in the euro area and the US, broad noncore liabilities as a share of GDP swelled between end-2002 and end-2008. However, by Q3:2013. noncore liabilities had fallen close to their end-2002 levels. The United Kingdom's shadow banking system nearly doubled in the run up to the crisis but unlike the euro area and the US, the SBS fell only marginally after the crisis. In Japan, broad noncore liabilities as a share of GDP remained almost identical before and after the crisis.

\section{Figure 4. Evolution of the Shadow Banking System in Selected Jurisdictions} (share of broad noncore liabilities as a percent of GDP)

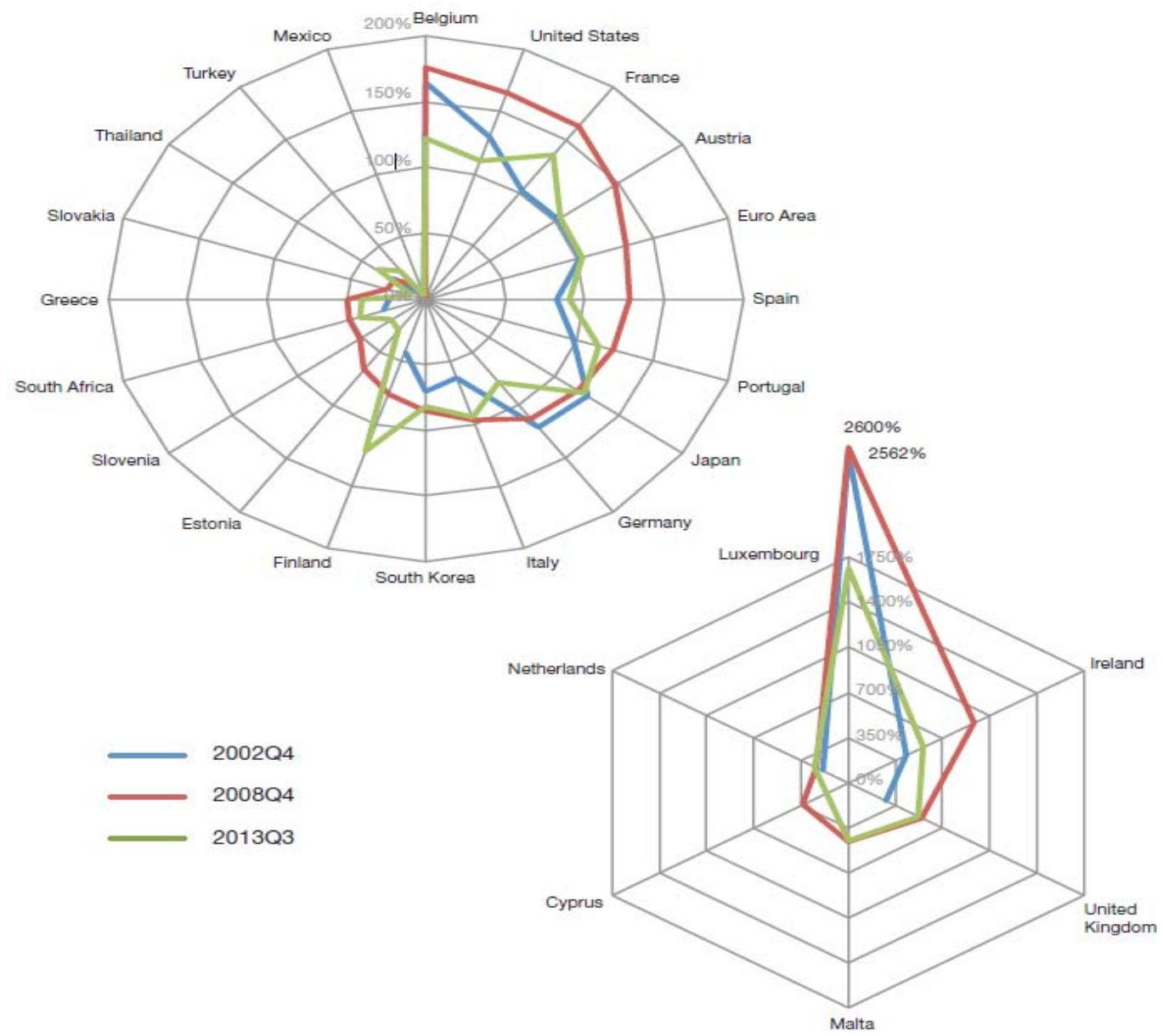

Source: IMF staff estimates.

\footnotetext{
${ }^{22}$ The full time series are presented in Appendix III.
} 
For most other countries in our sample, broad noncore liabilities as a percent of nominal GDP peaked during the periods immediately preceding the global financial crisis (see Appendix III, table 1). For the four emerging market economies (Mexico, South Africa, Thailand, and Turkey), noncore liabilities tend to be much smaller than the average in the overall sample. However, unlike most other countries, their size relative to GDP has grown more steadily during the observed periods, with less significant fluctuations during the crisis. Figure 5 presents the full time series for our core and noncore liabilities measures for six selected jurisdictions, which represent four of the largest SBS jurisdictions and two emerging market economies.

An interesting and perhaps not so obvious finding shown in Figure 5 is the difference between the broad and the narrow noncore liabilities measures. This difference can be interpreted as the size of intra-SBS balance sheet positions (e.g., an SBS institution financing another SBS institution using an SBS-like instrument). In terms of contribution of intra-SBS positions within total broad noncore liabilities, Japan and the United States led all countries for nearly every year in the sample. ${ }^{23}$

Additionally, we find that for the euro area, Japan, and the United Kingdom, the level of interconnection within the SBS has remained constant over the period considered and, thus, seems to be unrelated to the actual level of noncore liabilities. Only in the case of the United States do we find that the level of interconnection declines with the post-crisis deleveraging of SBS, though the level of interconnection remained constant over the period Q4:2001-Q3:2008.

\footnotetext{
${ }^{23}$ The noncore measure for Japan includes noncore liabilities issued by Public Financial Institutions (PFIs), which transact heavily amongst themselves. These intra-PFI positions help explain the large difference between the narrow and broad noncore measures for Japan.
} 

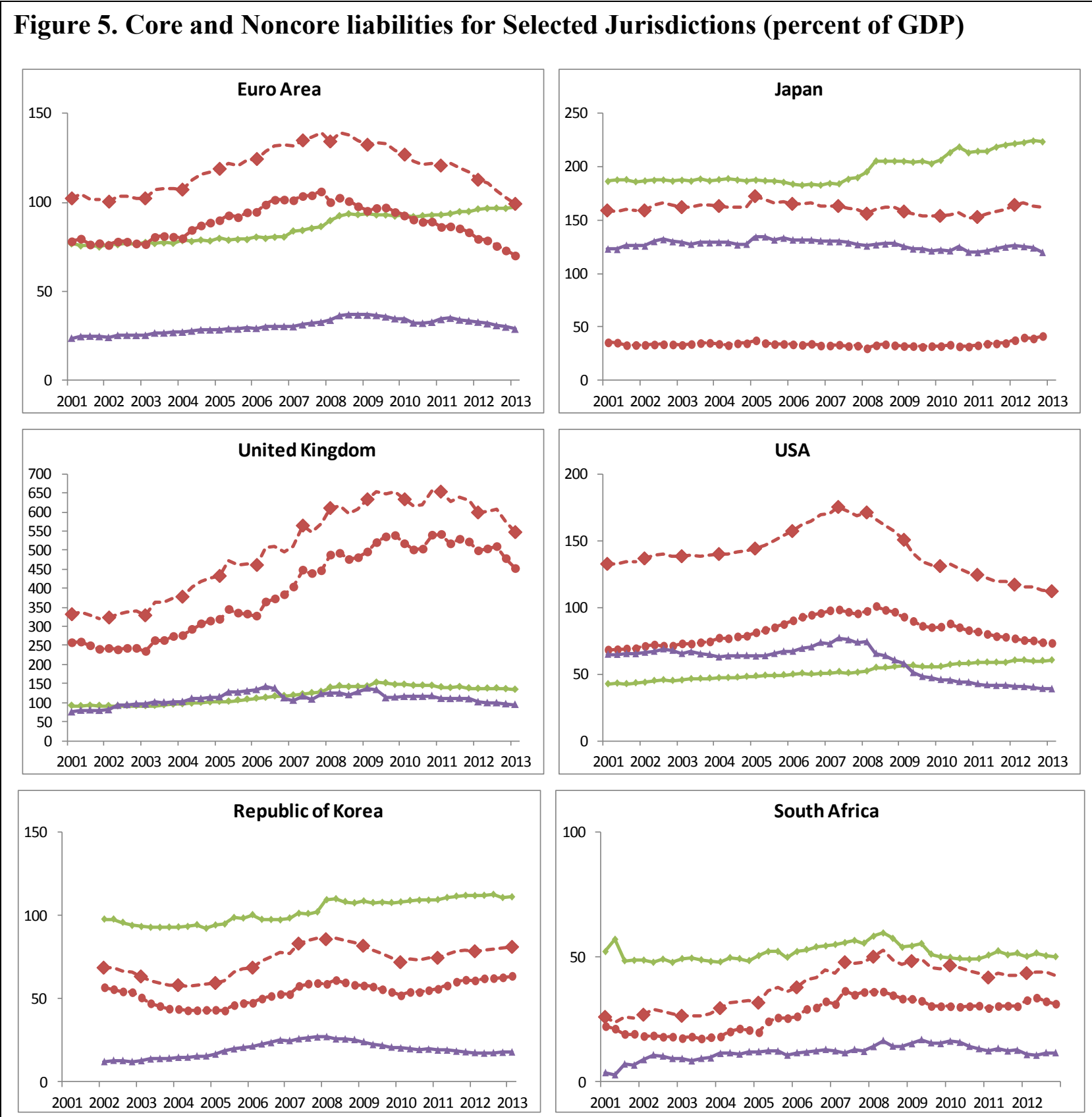

$\longrightarrow$ Core $\quad-$ - Noncore (broad) $\quad-$ Noncore (narrow) $\quad \longrightarrow$ Intra-SBS

Source: IMF staff estimates.

Turning now to the components of noncore liabilities, Figure 6 decomposes broad noncore liabilities for the United States between the Q4: 2001 and Q4:2013. In spite of OFIs being the largest issuers of SBS-like liabilities in the United States, banks make up about 10 percent of noncore liabilities at end-2013, which are not captured by other estimates based on the size of the OFC sector (e.g., by the Federal Reserve Board measure). For all periods, OFI securities 
represent the majority of noncore liabilities for the US, followed by MMF shares. Throughout the observed period, OFI debt securities and MMF shares consistently comprise more than 70 percent of total noncore liabilities. These two sources of funding also appear to have driven the build-up of noncore liabilities during the peak quarters prior to the crisis. OFI noncore liabilities and MMF shares are also the source of the decline in noncore liabilities since the peak pre-crisis period, with both contracting by over 25 percent.

\section{Figure 6. United States: Instrument Composition of Broad Noncore Liabilities (USD, trillion)}

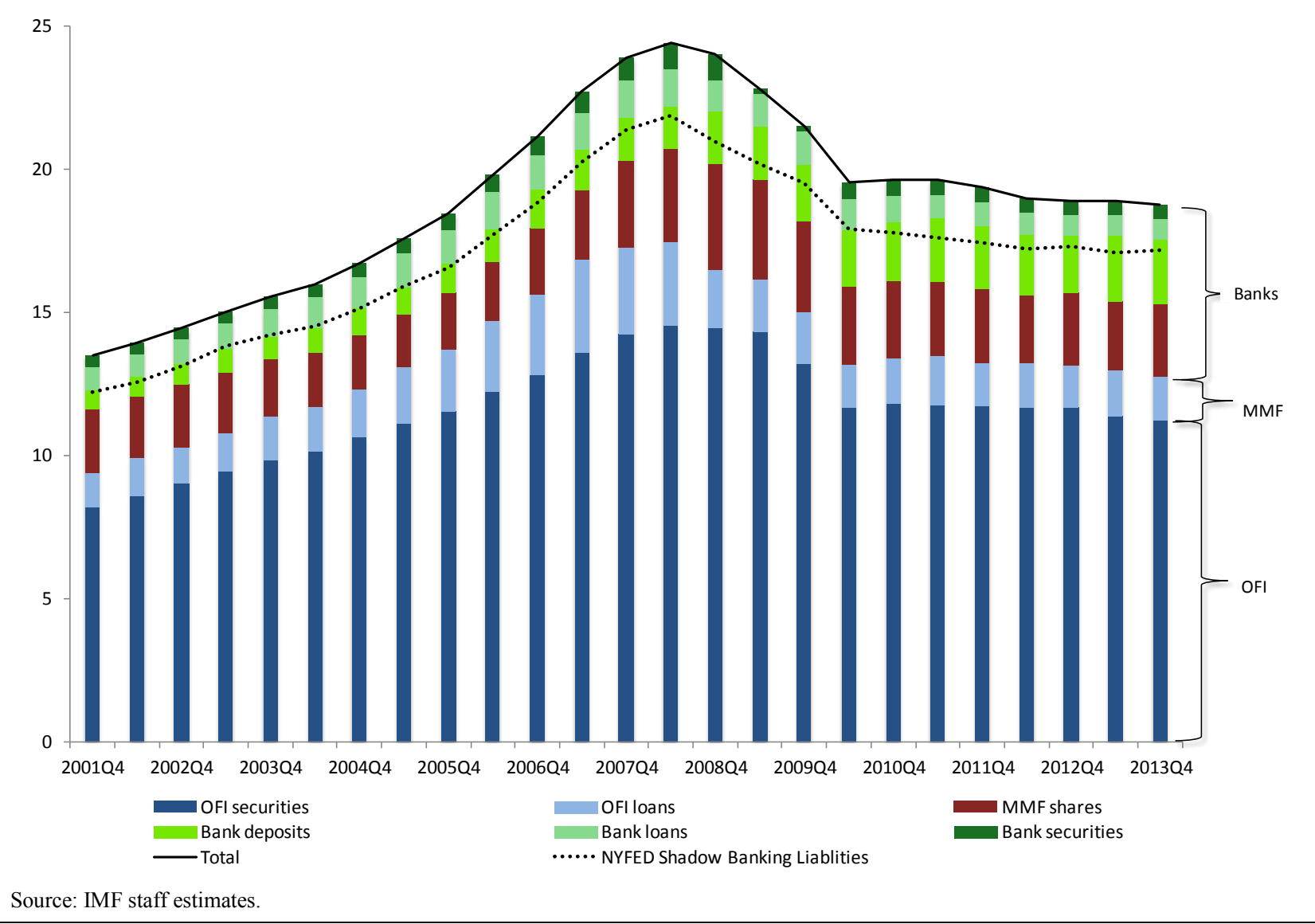

For euro area countries, the magnitude of noncore liabilities in comparison to core liabilities varies greatly across the sample. In some smaller countries (Ireland and Luxembourg), the large size of noncore liabilities reflects the magnitude of the financial system relative to the size of the domestic economy and, in particular, the importance of foreign funding (included in noncore liabilities), reflecting their roles as international financial hubs. Figure 7 provides an instrument breakdown of broad noncore liabilities for the euro area. Compared with the US, the share of noncore liabilities issued by banks is much larger, standing at about 70 percent in the fourth quarter of 2013. As total issuance of noncore liabilities in the euro area and the US have a similar magnitude, our calculations show that the OFI sector in the euro area is much smaller than in the US. Figure 8 shows noncore liabilities across different countries in Europe. 


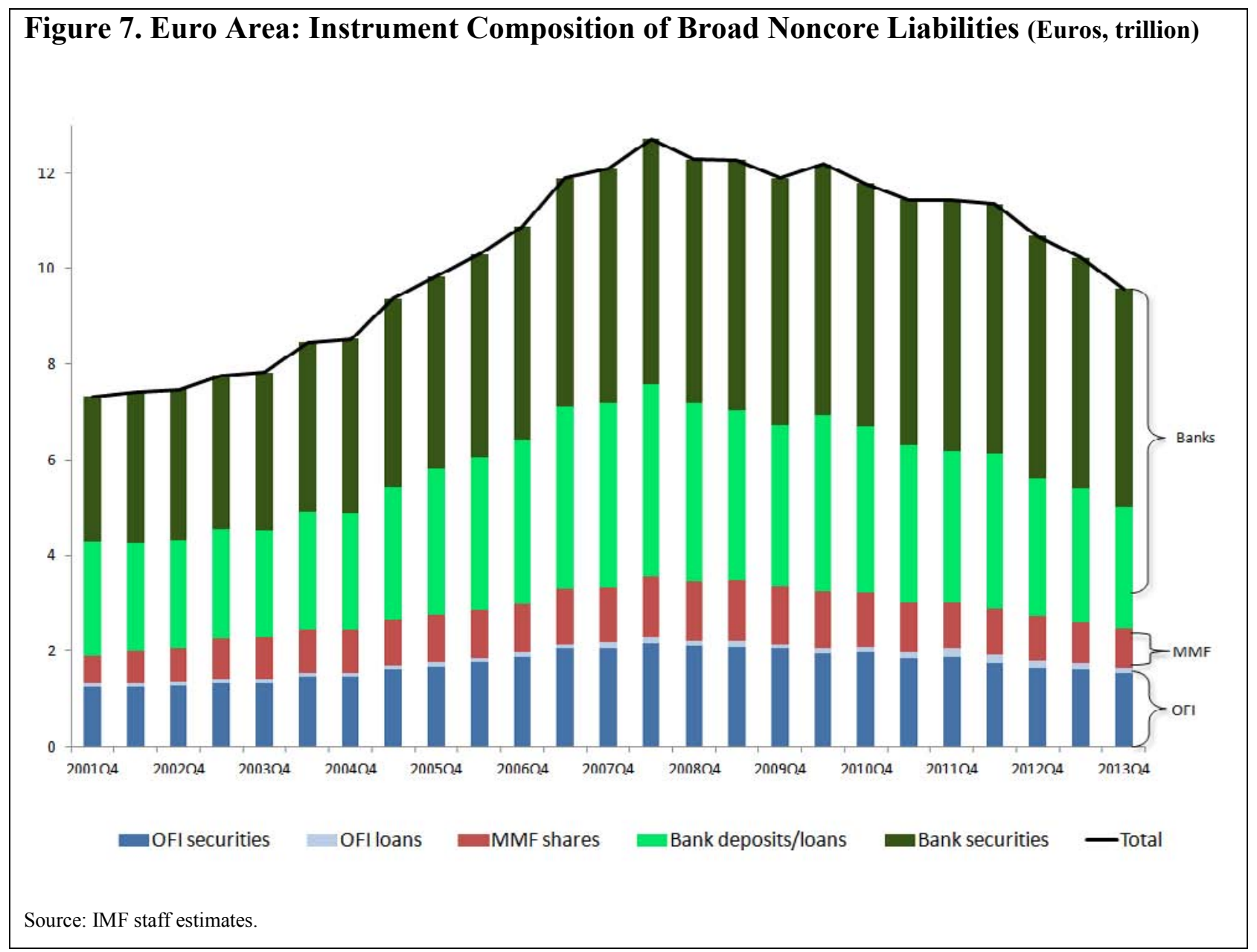


Figure 8. Core and Noncore Liabilities in Europe in 2008:Q3 and 2013: Q4
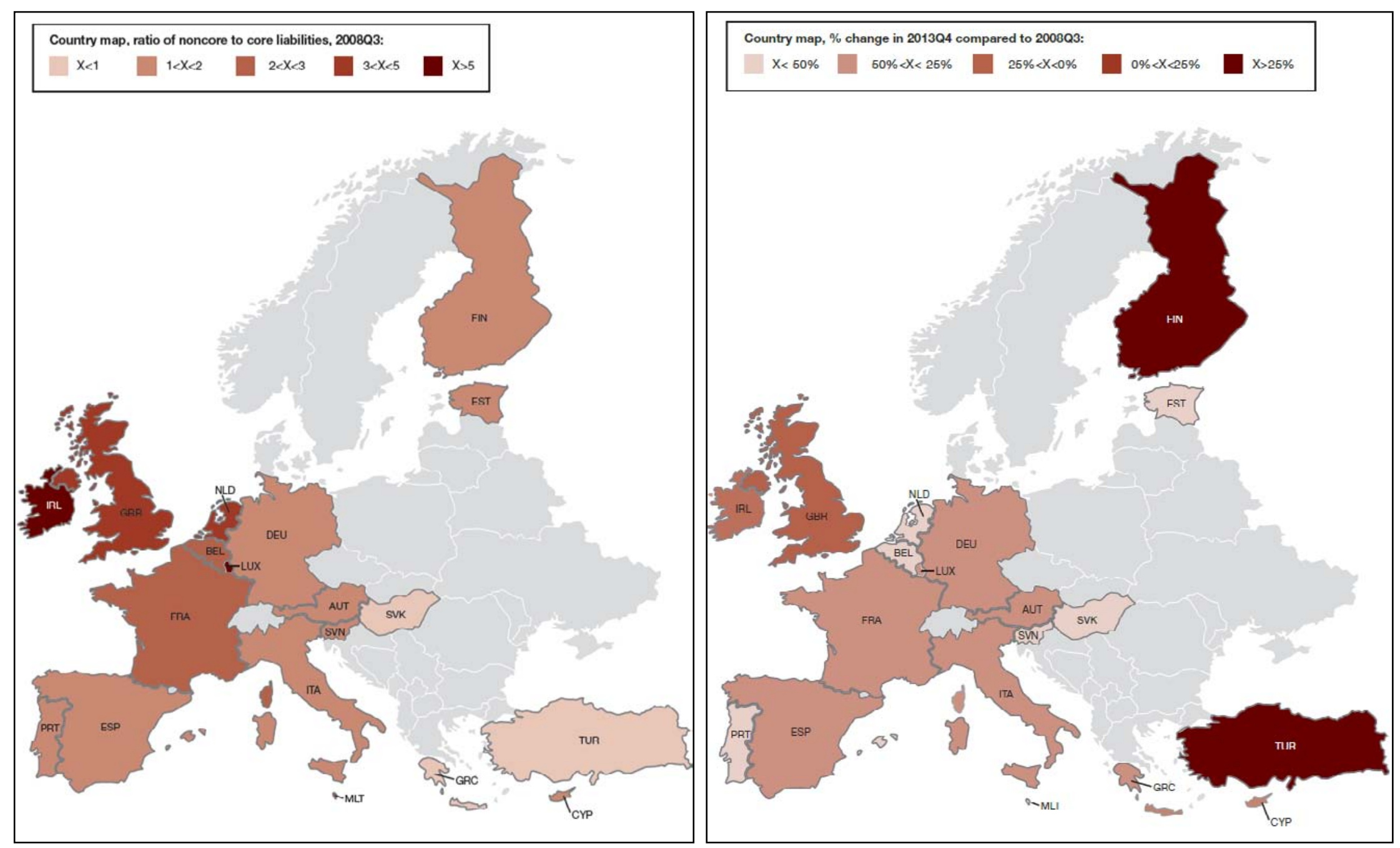

Source: IMF staff illustration. 


\section{B. Growth rates and variability}

Core liabilities seem to follow a more stable pattern relative to the two measures of noncore liabilities in terms of growth rates. In particular, they show a rather steady growth over the time period considered for the majority of countries in our sample. Noncore liabilities behaved rather differently across the sample countries. In terms of GDP share, noncore liabilities followed a bell-shaped curve in the euro area and the United States, the peak occurring during the financial crisis in both jurisdictions. Noncore liabilities seem to have been growing in the United Kingdom through 2010, with a comparatively smaller decline in recent years. The estimates for Japan follow a rather flat trajectory for both the broad and narrow noncore liabilities measures.

Average year-on-year growth rates in core liabilities displayed a narrow range of variability across the sample whereas average growth rates for both noncore liabilities measures had greater variation. Overall, average pre-crisis growth rates for both core and noncore liabilities were consistently positive although the noncore liabilities measure had higher average year-on-year growth rates for most of our sample. After the crisis, average growth rates for noncore liabilities turned negative for most countries. However, average growth rates for core liabilities remained positive in all but three countries in the sample (Cyprus, Greece, and Ireland).

Looking at period-to-period variation, Figure 9 presents the quarterly changes of core and noncore liabilities over time for the three largest jurisdictions in our sample by overall SBS size. The charts for the United States and the euro area depict a rather similar picture for the two jurisdictions, in which core liabilities tend to grow with a stable pattern over time, as reflected by the almost constant quarterly flows. On the other hand, in these two jurisdictions noncore liabilities grow more rapidly than core liabilities until the financial crisis, after which the quarterly flows become largely negative. The picture for the United Kingdom is instead rather different, with very small (albeit positive) quarterly flows of core liabilities and very large but volatile flows of noncore liabilities in some periods also after the crisis. The three cases highlight that, notwithstanding the assumptions required to calculate core and noncore liabilities from available data, the two sets of liabilities show properties that are worth examining in more detail and that may carry different implications for the financial system and how this develops over the business cycle. 


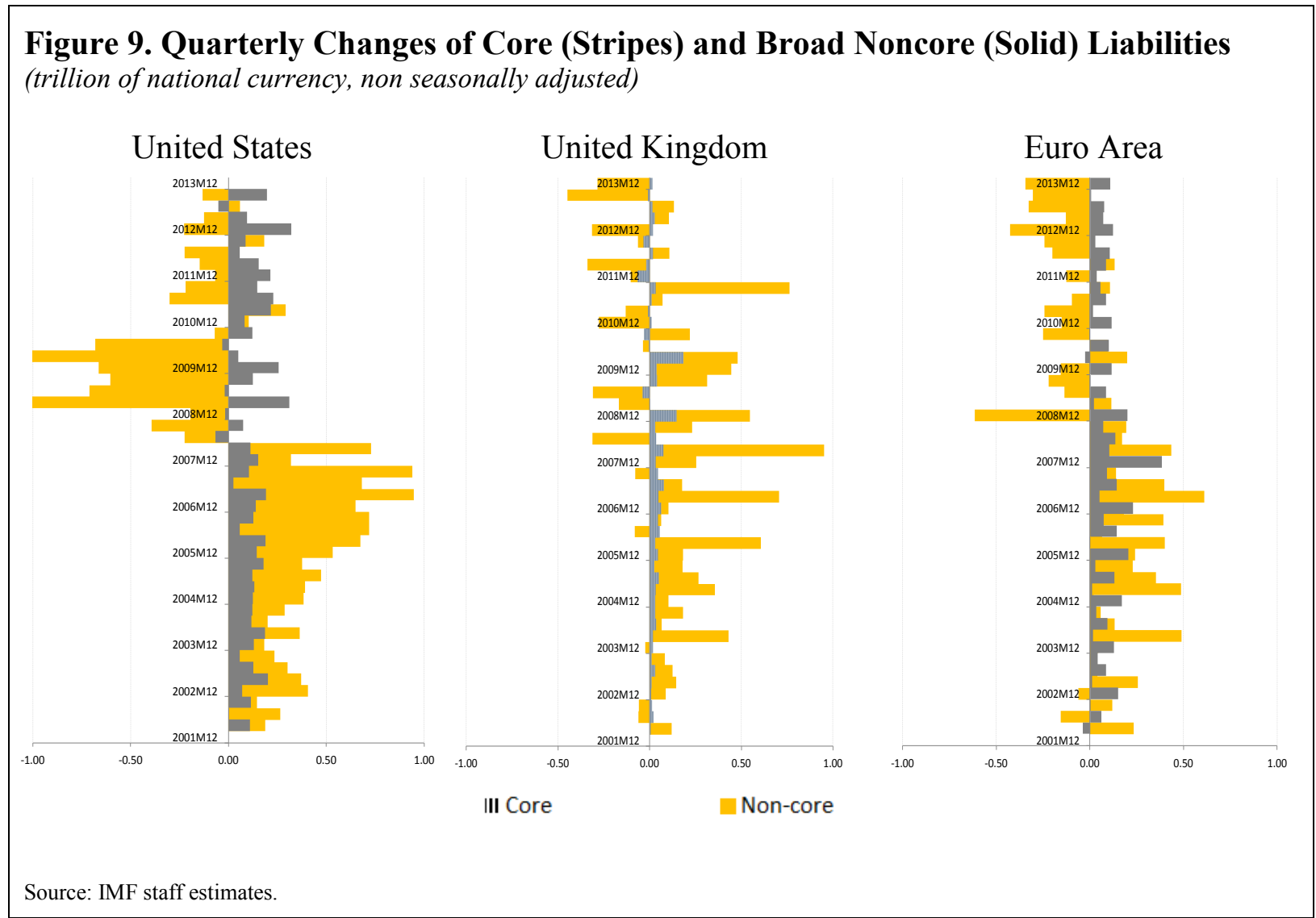

\section{Comparison with FSB estimates}

The FSB estimated the size of the SBS for 13 jurisdictions in our sample. The estimates refer to the size of the OFI sector ${ }^{24}$ in a given jurisdiction based on total OFI assets, and are provided on an annual basis from 2002 to 2013.

Figure 10 compares and contrasts our noncore liabilities measures to the FSB estimate for six jurisdictions in our sample, which represent G-7 countries (except one) and two emerging market economies. The two main differences between our measure and the FSB estimate are that: (i) the FSB includes shares issued by IFs, which we exclude from noncore liabilities; and (ii) the FSB excludes bank liabilities that in our approach belong to the noncore liabilities measures.

In the case of the United States, the FSB figure roughly follows the trends of our broad noncore liabilities measure until mid-2009, when the FSB estimate trends upward while our measure

\footnotetext{
${ }^{24}$ According to the FSB methodology, OFIs include "all financial institutions that are not classified as banks, insurance companies, pension funds, public financial institutions, central banks, or financial auxiliaries." FSB (2013), page 8 , footnote 25 .
} 
declines. The similar trend is due to the facts that (i) the largest contributors to the US noncore liabilities are OFI debt securities, which are included in both measures; and (ii) the contribution of the banking sector to overall noncore liabilities is relatively small. The large divergence in post-crisis periods is instead due to the rebound of IF shares issued, which are not included in our measure.

For Japan, the FSB figure lies between our two noncore liabilities measures for all periods although the FSB figure is closer to our narrow figure. In particular, our broad measure of noncore liabilities is roughly three times larger than the FSB estimate, due to the inclusion of internal positions between PFIs (see the explanation in footnote 23) which are excluded in the FSB estimate.

For the euro area, our measure is not easily comparable to the FSB one. Banks have a very large share in our measure of noncore liabilities, while they are excluded by the FSB. Secondly, our noncore liabilities measure for the euro area only includes securitization vehicles among OFI liabilities, while the FSB measure's institutional coverage is wider. Finally, in the case of UK, the differences between the two series need to be interpreted with caution given the data gaps in calculating our noncore liabilities measures, especially the narrow measure.

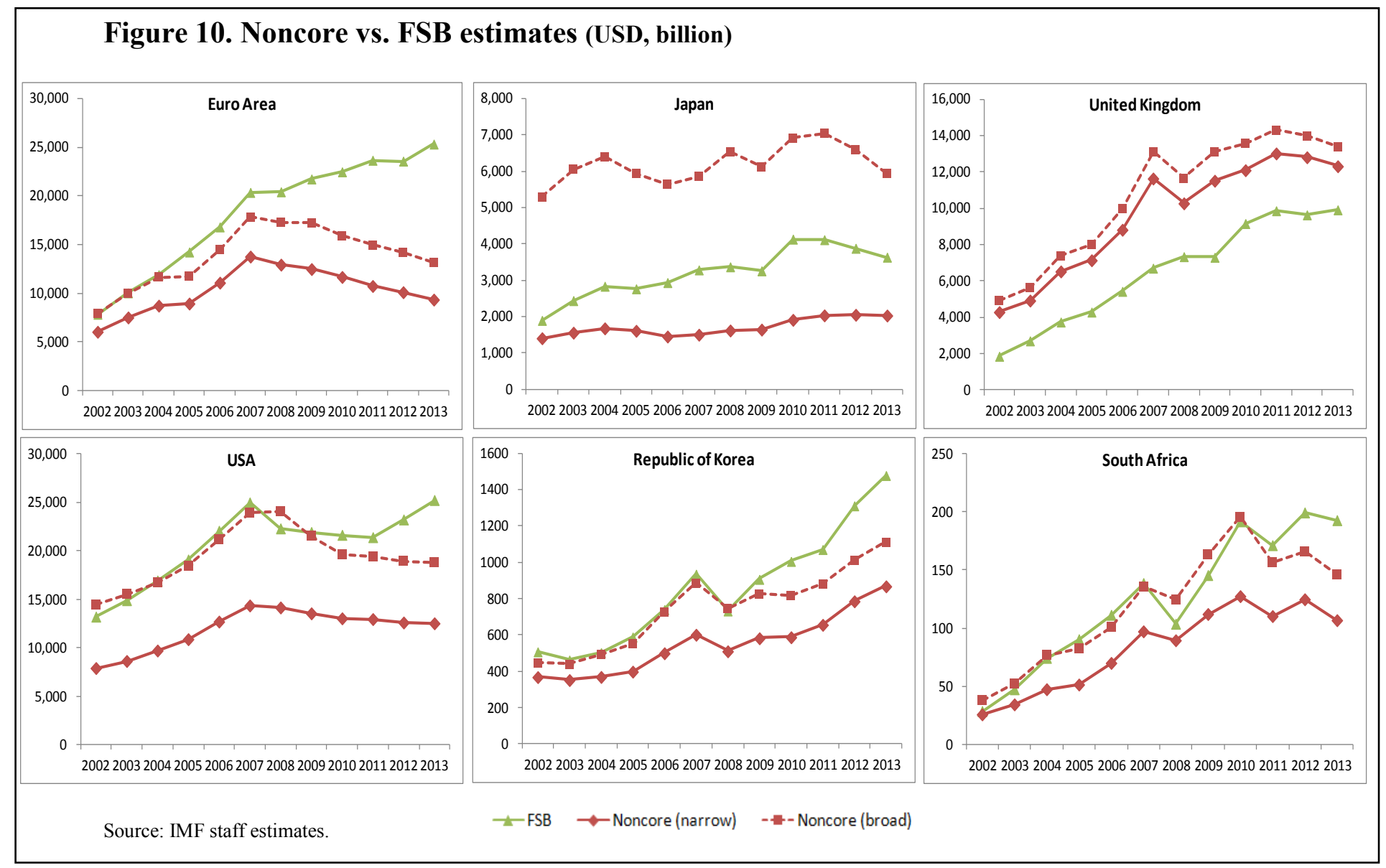




\section{Data GAPS}

As discussed earlier, the SRFs provided the bulk of the source data for this exercise, namely the issuing subsector of financial corporations, the financial instrument, and the counterpart sector. Nonetheless, not all countries report the SRFs, in particular for OFCs. As a result, we turned to alternative data sources for countries not reporting SRFs or reporting partial data on OFCs. Financial statistics (flow of funds data) proved to be another useful source of data. However, few countries compile and publish these data to the level of detail needed for the exercise. ${ }^{25}$

With both the SRFs and alternate data sources accounted for, insufficient granularity with regards to different types of OFCs and subcategories of some instruments (particularly debt securities) prevent the full application of our methodology. For example, certain debt securities, such as certificates of deposit and long-term bonds, represent more traditional, stable financing sources. However, given that the SRFs and most other data sources provide no additional breakdown of debt securities, we included all debt securities into noncore liabilities. Similarly, the majority of our data sources did not provide granular balance sheet data for the OFC subsectors. To overcome these data gaps we made some estimations, especially when deriving the narrow noncore liabilities measure to exclude intra-SBS positions. Additionally, in some cases, data were available for a more limited set of periods.

A further complication for this exercise stemmed from differences in terminology across countries. For example, the equivalents of MMFs use different names across countries. Similarly, instruments such as debt securities spanned a wide range of terminologies depending on the data source. Finally, while the SRFs contain a standardized set of metadata, the metadata accompanying alternate data sources used in our analysis were scarce and not focused on essential aspects, such as the types and definitions of institutions, instruments and counterparts covered.

\section{ILlUSTRATIVE ANALYSIS}

To illustrate some possible uses of our indicators, we show in this section some analytics to relate our measures of core and noncore liabilities to the wider economic cycle. The analysis presented here is meant to showcase the usefulness of the framework we propose and to pave the path for its further application. One specific aspect that may require further work is the refinement of the boundary between core and noncore liabilities for certain borderline instrument subcategories (e.g., debt securities). Further, with improvements in balance sheet data availability for subcategories of OFCs, better precision may be achieved in terms of their coverage in the noncore liabilities measure. In applying the framework to a specific country,

\footnotetext{
${ }^{25}$ Appendix II contains a brief description of the source data used for each of the 26 countries and any countryspecific deviations from the methodology laid out in Section 3.
} 
these refinements should of course be tailored to the specific characteristics of the financial system being examined.

In particular, we want to show how the funding structure of the financial system changes with the business cycle to assess whether noncore liability growth outpaces growth in core liabilities during economic booms. To do so, we construct an indicator denoted noncore ratio, computed as the ratio of broad noncore liabilities to the sum of core and broad noncore liabilities. This indicator reflects the one used by Shin and Shin (2010) for measuring bank noncore liabilities in Korean M2, but adds noncore liabilities of OFIs.

Table 2 shows the summary statistics of the annual growth rates of core and broad noncore liabilities. In addition, it shows the correlations between the growth rates of the noncore ratio indicator and GDP. As argued in Section V, the growth rate of the noncore liabilities measure features a much greater variability over time compared to the core indicator's one. In the case of the United States and euro area, the standard deviation of the noncore liabilities growth rates is more than double that of core liabilities growth.

Table 2. Summary statistics

Columns 1 and 2: standard deviation of annual growth rates

Columns 3 through 6: linear correlation coefficients of annual growth rates of noncore ratio and GDP

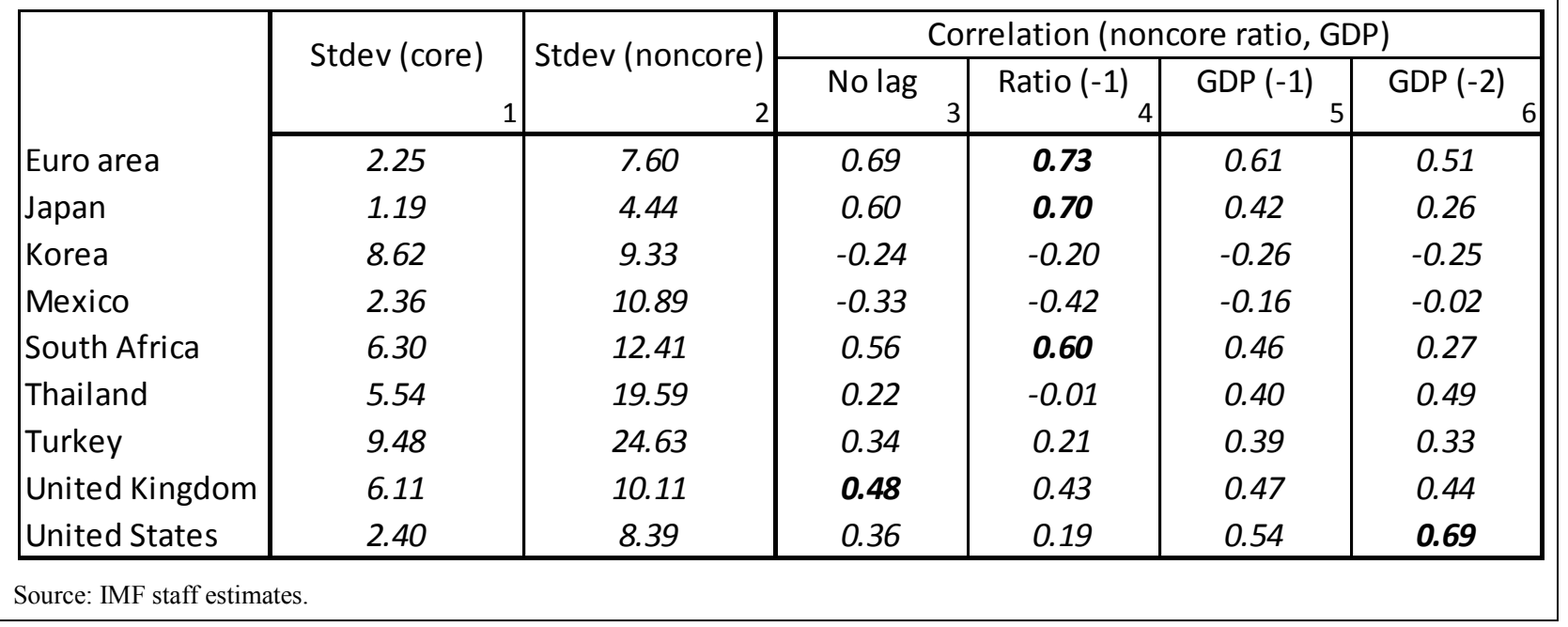

The second part of the table summarizes the cyclical behavior of the noncore ratio indicator we developed. We base our analysis on linear correlations between the growth rates of the noncore ratio and of nominal GDP, without regard to causation. We evaluate the linear correlation at different lags of each variable, and report in the table those that produced the most significant results. The broad results of this simple analysis are rather mixed across countries. Starting with the largest jurisdictions, we find evidence of procyclicality for the noncore ratio indicator in both the US and the euro area. The strongest correlations we find for both are approximately 0.7. However, in the case of the US, we find that GDP growth leads the rebalancing of the funding 
structure by about two quarters, whereas for the euro area we find that the two growth rates correlate with no lag.

In order to better illustrate this finding, we plot the annual growth rates of the noncore ratio and of GDP for the US and the euro area. Figure 11 shows for the US and the euro area that the growth rate of the share of noncore liabilities follows closely the GDP growth. One way to interpret this is that (i) balance sheet expansions during the pre-crisis credit boom were largely funded through noncore liabilities and, likewise, (ii) the significant deleveraging of the postcrisis periods has affected mostly noncore liabilities. This result is also consistent with that of Shin and Shin (2010), where the authors, using data for Korea, find that noncore liabilities are procyclical. In our paper, we are unable to replicate the positive correlation between GDP and noncore liabilities for Korea, most likely due to the limited time series span available in the SRF, which does not cover the downturn in late 1990s. ${ }^{26}$

\section{Figure 11. Growth of Noncore Ratio Indicator and GDP for the US and the Euro Area (annual percentage changes)}

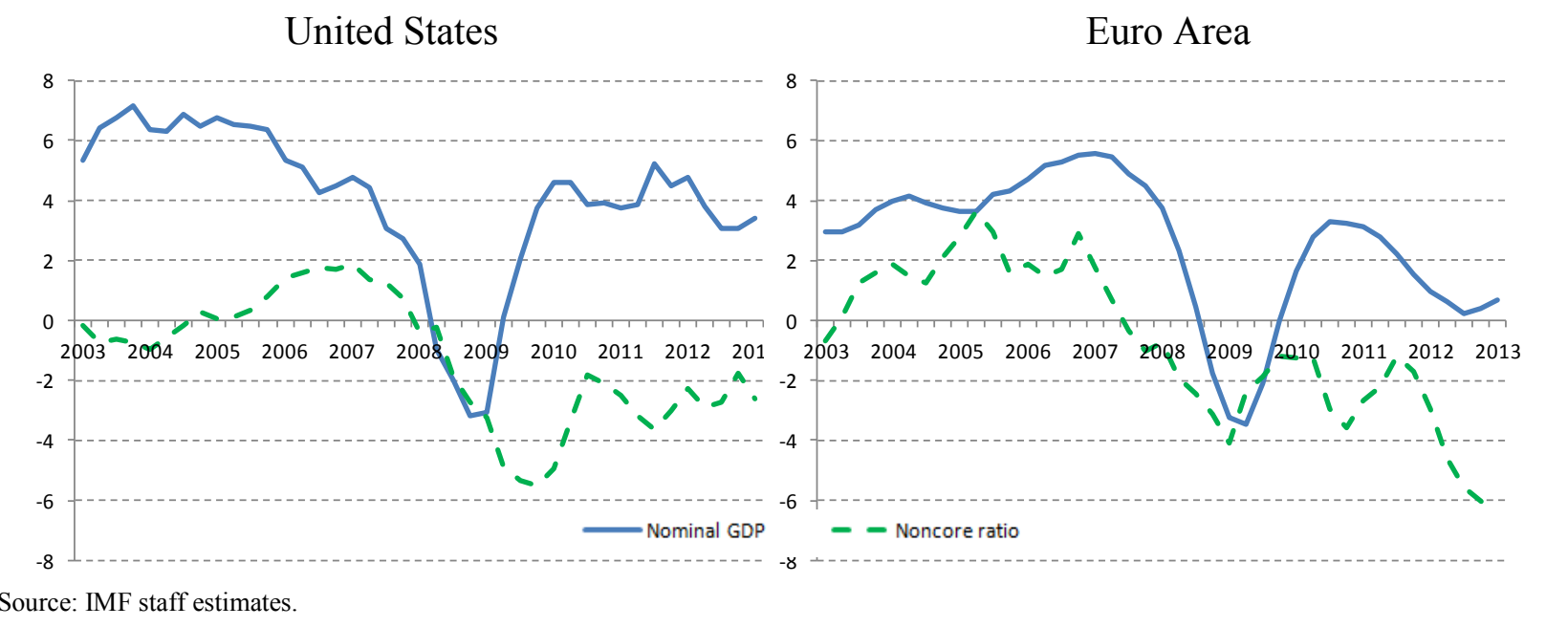

As for other jurisdictions, we find significant positive correlation for Japan, where the growth rates of GDP and of the noncore ratio indicator have a correlation coefficient of 0.7 . In the case of the UK, the result is not in line with our main findings. This is due to the fact that, in the UK, both core and noncore liabilities have continued growing after the financial crisis and, thus, their growth has not shown the procyclical behavior to the same extent as observed in the US and the euro area. This is reflected in the noncore ratio for the UK showing almost no change over time. Finally, for the remaining countries we find inconclusive evidence of noncore liabilities being procyclical. Noncore liabilities data for Turkey and South Africa do not go through a cycle

\footnotetext{
${ }^{26}$ Data in Shin and Shin (2010) go back to the early 90s, however such time series is not available in the SRF database. Our time series begin at end-2001 for most countries.
} 
during the considered periods, therefore the positive correlation between GDP growth and the growth of the noncore ratio indicator is largely a spurious result. It reflects the fact that GDP, core liabilities and noncore liabilities all grow over the horizon considered, but noncore liabilities grow faster than core liabilities.

\section{Conclusions}

This paper proposes a new measure of the SBS, based on the expansion of the noncore liabilities concept developed in Shin and Shin (2010), to encompass all noncore liabilities of both banks and nonbank financial institutions. A key feature of our approach is that all financial institutions involved in the credit intermediation chain may potentially issue SBS-like liabilities. We show that banks issue a large portion of noncore liabilities relative to the total, particularly in the euro area. Namely, while banks issue only about 10 percent of total noncore liabilities in the US as of end-2013, in the euro area their share in total noncore liabilities was approximately 70 percent. As argued in Shiller (2012) at the level of individual institutions, banks involvement in shadow banking activities can be significant.

Analyzing the data, we found that average growth rates for both noncore liabilities measures had greater variation during the observed period than core liabilities. Further, our results show that in many of the jurisdictions considered, noncore liabilities are procyclical. These findings are consistent with some of the main findings in Shin and Shin (2010).

An additional value added of our approach is that it generates data on intra-SBS activities, derived as difference between the estimation of broad and narrow SBS measures. The inclusion of intra-SBS positions in the broad measure allows tracking overall SBS activity and its total exposures, whereas the narrow measure reflects the net exposure of the SBS to macroeconomic sectors outside the SBS, or vice versa. The level of intra-SBS activities can also provide useful insights on the level of interconnectedness within SBS. Looking at the data results, we found that for many jurisdictions, the level of intra-SBS noncore liabilities remained relatively constant over time.

This paper also highlights some data gaps that, if bridged, would allow a more accurate application of the methodology that we developed. In particular, more granular data on subcategories of financial instruments (e.g., debt securities) issued by both banks and OFIs would allow a better classification of these instruments into core and noncore liabilities measures. Furthermore, improving the availability of separate balance sheet data for different types of OFCs, would permit a more accurate identification of issuers of SBS-like liabilities. This, in turn, coupled with better information on counterpart sectors, would allow the development of improved measures of narrow SBS and intra-SBS positions. Finally, temporally consistent historical data covering periods prior to the recent global financial crisis would enhance the application of our approach. 
The noncore liabilities approach developed in our paper lends itself to several applications. Most importantly, it can serve as an additional analytical tool for IMF surveillance, national macroprudential authorities, and researchers to gain a better understanding of the drivers of risk build-up and financial crises. The illustrative applications of our measures are meant to showcase the usefulness of the proposed approach. We do not consider the specific application of the approach presented in this paper to be conclusive in terms of types of financial institutions covered, the identified holders of noncore liabilities, and the classifications of the component financial instruments. Further analysis and testing of the developed measures would help facilitate forming a broader view on the calculation and application of the proposed approach. 


\section{Appendix I. Comparison of Selected SBS Measurement Methodologies ${ }^{27}$}

\begin{tabular}{|c|c|c|}
\hline Source & Institutional Coverage & Instrument Coverage \\
\hline \multicolumn{3}{|l|}{ IMF: } \\
\hline $\begin{array}{l}\text { 1) Institutional Cash Pools and } \\
\text { the Triffin Dilemma of the U.S. } \\
\text { Banking System (Pozsar, 2008) }\end{array}$ & $\begin{array}{l}\text { Broker-dealers, government sponsored } \\
\text { vehicles, investment conduits and limited } \\
\text { purpose finance companies, SIVs }\end{array}$ & $\mathrm{N} / \mathrm{A}$ \\
\hline $\begin{array}{l}\text { 2) Exploring the Dynamics of } \\
\text { Global Liquidity (Chen et al., } \\
\text { 2012) }\end{array}$ & Banks, MMFs, OFCs & $\begin{array}{l}\text { Nonresident deposits in commercial } \\
\text { banks (hence cross-border deposits } \\
\text { would be considered noncore) and } \\
\text { other deposit corporations as well as } \\
\text { loans and securities (other than shares) } \\
\text { of commercial banks, nonbanks and } \\
\text { other financial intermediaries }\end{array}$ \\
\hline $\begin{array}{l}\text { 3) Shadow Banking: Economics } \\
\text { and Policy (Claessens et. al, } \\
\text { 2012) }\end{array}$ & Banks, dealer banks, and SPVs & Repos, securities, derivatives \\
\hline $\begin{array}{l}\text { 4) Global Financial Stability } \\
\text { Report, Chapter } 2 \text { - Flow of } \\
\text { Funds approach (October 2014) }\end{array}$ & $\begin{array}{l}\text { MMFs, financial leasing companies, } \\
\text { broker/dealers, securitization vehicles, } \\
\text { financial holding corporations, venture } \\
\text { capital corporations, development capital } \\
\text { companies and other entities. }\end{array}$ & $\mathrm{N} / \mathrm{A}$ \\
\hline \multicolumn{3}{|l|}{ IMF (STA): } \\
\hline $\begin{array}{l}\text { 1) Mapping the Shadow } \\
\text { Banking System Through a } \\
\text { Global Flow of Funds Analysis } \\
\text { (Errico et al., 2014) }\end{array}$ & Banks, OFIs & $\begin{array}{l}\text { Deposits (including foreign currency } \\
\text { deposits) at ODCs excluded from } \\
\text { broad money; debt securities issued } \\
\text { by ODCs, MMFs, and OFCs; loans } \\
\text { received by ODCs and OFCs; and } \\
\text { nonresidents' deposits with ODCs } \\
\text { and OFCs. }\end{array}$ \\
\hline $\begin{array}{l}\text { 2) Shedding Light on Shadow } \\
\text { Banking (Harutyunyan et al., } \\
\text { 2014) }\end{array}$ & Banks, MMFs, OFIs & $\begin{array}{l}\text { Restricted deposits, MMF shares, debt } \\
\text { securities, loans }\end{array}$ \\
\hline $\begin{array}{l}\text { 3) Global Financial Stability } \\
\text { Report, Chapter } 2 \text { - Noncore } \\
\text { Liability measure (October } \\
\text { 2014) }\end{array}$ & Banks, MMFs, OFIs & $\begin{array}{l}\text { Restricted Deposits, MMF shares, debt } \\
\text { securities, loans }\end{array}$ \\
\hline \multicolumn{3}{|l|}{ OECD: } \\
\hline $\begin{array}{l}\text { Financial Statistics for } \\
\text { Measuring the Structure and } \\
\text { Size of the Shadow Banking } \\
\text { System (Sartoru and Cavieres, } \\
\text { 2012) }\end{array}$ & $\begin{array}{l}\text { OFIs (including SPEs and financial } \\
\text { vehicle corporation) }\end{array}$ & $\begin{array}{l}\text { Currency, deposits, loans (by ODCs), } \\
\text { securities other than shares (bonds, } \\
\text { negotiable certificates of deposit, } \\
\text { commercial paper, debentures, asset } \\
\text { backed securities, and similar } \\
\text { instruments normally traded in the } \\
\text { financial markets) except financial } \\
\text { derivatives or shares and other equities } \\
\text { (for insurance corporations) }\end{array}$ \\
\hline
\end{tabular}

${ }^{27}$ Based on authors' understanding of the cited works. 


\begin{tabular}{|c|c|c|}
\hline Source & Institutional Coverage & Instrument Coverage \\
\hline \multicolumn{3}{|l|}{ ECB: } \\
\hline $\begin{array}{l}\text { Shadow Banking in the Euro } \\
\text { Area - An Overview (Bakk- } \\
\text { Simon et al., 2012) }\end{array}$ & $\begin{array}{l}\text { All OFIs (financial institutions other than } \\
\text { those included in the sectors monetary } \\
\text { financial institutions and the insurance } \\
\text { corporations and pension funds) }\end{array}$ & N/A \\
\hline \multicolumn{3}{|l|}{ FSB: } \\
\hline $\begin{array}{l}\text { Global Shadow Banking } \\
\text { Monitoring Report } 2013 \text { (FSB, } \\
\text { 2013) }\end{array}$ & $\begin{array}{l}\text { OFIs (all financial institutions that are } \\
\text { not classified as banks, insurance } \\
\text { companies, pension funds, public } \\
\text { financial institutions, central banks or } \\
\text { financial auxiliaries) }\end{array}$ & N/A \\
\hline \multicolumn{3}{|l|}{ US: } \\
\hline $\begin{array}{l}\text { 1) Shadow Banking and the } \\
\text { Financial Crisis (FCIC, 2010) }\end{array}$ & $\begin{array}{l}\text { MMMFs, hedge funds, investment } \\
\text { banks, finance companies, asset-backed } \\
\text { commercial paper conduits, government- } \\
\text { sponsored enterprises, other financial } \\
\text { guarantors }\end{array}$ & $\begin{array}{l}\text { Unsecured commercial paper and } \\
\text { asset-backed commercial paper, repos, } \\
\text { securities lending, auction rate } \\
\text { securities, derivatives }\end{array}$ \\
\hline $\begin{array}{l}\text { 2) The Deloitte Shadow } \\
\text { Banking Index (Deloitte Center } \\
\text { for Financial Services, 2012) }\end{array}$ & $\begin{array}{l}\text { MMFs, government-sponsored entities, } \\
\text { SPVs }\end{array}$ & $\begin{array}{l}\text { ABCP conduits, } \mathrm{ABS} \text {, non-agency } \\
\mathrm{MBS}, \mathrm{CDOs} \text {, repos, securities lending, } \\
\text { and agency mortgage backed securities }\end{array}$ \\
\hline $\begin{array}{l}\text { 3) FRBNY: Shadow Banking } \\
\text { (Pozsar, Adrian, Ashcraft and } \\
\text { Boesky, 2010) }\end{array}$ & $\begin{array}{l}\text { finance companies, limited-purpose } \\
\text { Finance companies, structured } \\
\text { investment vehicles, credit hedge funds, } \\
\text { money market mutual funds, securities } \\
\text { lenders, and government-sponsored } \\
\text { enterprises }\end{array}$ & $\begin{array}{l}\text { Asset-backed commercial paper } \\
\text { (ABCP) conduits, asset-backed } \\
\text { securities, collateralized debt } \\
\text { obligations, and repo }\end{array}$ \\
\hline $\begin{array}{l}\text { 4) Financial Stability } \\
\text { Monitoring (Adrian, Covitz and } \\
\text { Liang, 2013) }\end{array}$ & $\begin{array}{l}\text { Securities broker-dealers, hedge funds, } \\
\text { private equity and other funds, asset } \\
\text { management firms, insurance companies } \\
\text { and pension funds, MMFs, other cash } \\
\text { management funds }\end{array}$ & $\begin{array}{l}\text { Tri-party repos, } \mathrm{ABCP} \text {, financial } \\
\text { commercial paper, uninsured } \\
\text { certificates of deposits, variable rate } \\
\text { demand obligations, tender option } \\
\text { bonds }\end{array}$ \\
\hline \multicolumn{3}{|l|}{ 0ther: } \\
\hline $\begin{array}{l}\text { 1) Noncore Bank Liabilities and } \\
\text { Financial Vulnerability (Hahm, } \\
\text { Shin and Shin, 2011) }\end{array}$ & Banks & $\begin{array}{l}\text { Time, savings and foreign currency } \\
\text { deposits, restricted deposits; } \\
\text { institutional money market mutual } \\
\text { funds, repurchase agreements }\end{array}$ \\
\hline $\begin{array}{l}\text { 2) Regulating Shadow Banking } \\
\text { (Schwarcz, 2012) }\end{array}$ & $\begin{array}{l}\text { SPEs (ABCP conduits, limited-purpose } \\
\text { finance companies and SIVs), finance } \\
\text { companies, hedge funds, mutual funds, } \\
\text { government sponsored entities and } \\
\text { investment banks }\end{array}$ & N/A \\
\hline $\begin{array}{l}\text { 3) Regulating the Shadow } \\
\text { Banking System (Gorton \& } \\
\text { Metrick, 2012) }\end{array}$ & MMFs, SPEs & $\begin{array}{l}\text { Demand deposits, repos, securitized } \\
\text { bonds and related assets, including } \\
\text { many classes of asset-backed } \\
\text { securities (ABS) and CDOs }\end{array}$ \\
\hline
\end{tabular}




\begin{tabular}{|l|l|l|}
\hline \multicolumn{1}{|c|}{ Source } & \multicolumn{1}{|c|}{ Institutional Coverage } & \multicolumn{1}{c|}{ Instrument Coverage } \\
\hline $\begin{array}{l}\text { 4) Shadowy Banking: Theft by } \\
\text { Safety Net (Kane, 2014) }\end{array}$ & $\begin{array}{l}\text { An institution or bank-sponsored SPV. It } \\
\text { covers any financial organization, } \\
\text { product, or transaction strategy that can } \\
\text { opaquely extract subsidies guarantees } \\
\text { from national and cross-country safety } \\
\text { nets by means of 'regulation-induced } \\
\text { innovation' }\end{array}$ & $\begin{array}{l}\text { Swaps, repurchase agreements, futures } \\
\text { contracts and AAA securitizations that } \\
\text { may trade for substantial periods of } \\
\text { time as if they carried zero } \\
\text { performance risk }\end{array}$ \\
\hline $\begin{array}{l}\text { 5) Bagehot was a Shadow } \\
\text { Banker: Shadow Banking, } \\
\text { Central Banking, and the Future } \\
\text { of Global Finance (Mehrling el } \\
\text { al., 2013) }\end{array}$ & $\begin{array}{l}\text { Money market funding of capital market } \\
\text { lending on the balance sheets of banks } \\
\text { and OFIs }\end{array}$ & $\begin{array}{l}\text { Residential mortgage backed securities } \\
\text { (RMBS), credit default swaps, interest } \\
\text { rate swaps, foreign exchange swaps }\end{array}$ \\
\hline $\begin{array}{l}\text { 6) Money and (Shadow) } \\
\text { Banking: A thought experiment } \\
\text { (Ricks, 2012) }\end{array}$ & $\begin{array}{l}\text { Maturity transformation outside banking } \\
\text { social contract }\end{array}$ & N/A \\
\hline
\end{tabular}




\section{Appendix II. Computation Details for Individual Countries}

For each country in our sample, we derived a core measure as well as the broad and narrow noncore measures using the methodology outlined in Section III. For each country, we began the compilation exercise using the SRFs for ODC and OFCs that are reported to the IMF. For each measure, individual balance sheets were needed for insurance corporations, pension funds, and non-MMF investment funds. Sectoral breakdowns for holdings of MMF shares were also needed. In many cases, these data could be obtained either through consultation with the national central bank or via central bank websites. Below is a detailed description of the data sources used for each country and any deviations from the benchmark methodology.

\section{Euro Area (total and individual countries)}

Data source(s): SRFs 2SR reported to the IMF; balance sheet data for OFCs sourced from the ECB's Investment Funds (IF) and Financial Vehicle Corporations (FVC) databases.

Deviations: securities issued by ODCs (including MMF shares issued) and OFIs are only partially sectorized in the euro area, therefore holdings by non-SBS and intra-SBS have to be approximated. OFC balance sheet data are only partially available at the ECB, namely only the IF, FVC and ICPF sectors are covered. For the purpose of our noncore indicators, OFI noncore liabilities for the euro area only include liabilities of FVC in the form of loans and debt securities issued. The remaining OFC sector liabilities included in our definition of shadow banking are not covered by published ECB statistics. Data for IF are available from 2008:4 and data for FVC from 2009:4; for the purpose of grossing up past periods, OFC liabilities are assumed to be growing at the same rate as liabilities issued by ODCs.

\section{Japan}

Data source(s): SRFs 2SR and 4SR reported to the IMF; additional detail sourced from Bank of Japan Flow of Funds database.

Deviations: ICPF holdings of securities and loans issued by domestic ODCs and OFIs were used to compile the narrow noncore measure. In some cases, the sectoral detail of ICPF and IF was not available for some securities and loans that these institutions hold as assets and are thus not included in the measure. The noncore measure also includes liabilities issued by PFIs.

\section{Korea}

Data source(s): SRFs 2SR reported to the IMF; Bank of Korea flow of funds database.

Deviations: For the narrow measure, sectoral detail of securities issued by OFIs was not available and thus includes counterparties other than the ultimate creditors. All certificates of 
deposit held by insurance corporations, pension funds and non-MMF investment funds were assumed to be issued by domestic financial institutions.

\section{Mexico}

Data source(s): SRFs 2SR and 4SR reported to the IMF.

Deviations: Due to lack of sectoral detail for insurance corporations, pension funds, and nonMMF investment funds, only the broad measure could be compiled. Non-MMF investment funds are captured in the $2 \mathrm{SR}$.

\section{South Africa}

Data source(s): SRFs 2SR and 4SR reported to the IMF; sub-sectoral detail on MMFs, nonMMF investment funds, insurance corporations and pension funds were obtained in consultation with the South African Reserve Bank.

\section{Thailand}

Data source(s): SRFs 2SR and 4SR reported to the IMF; data on MMF shares issued sourced from the Bank of Thailand monetary aggregates series.

Deviations: Due to lack of sectoral detail for insurance corporations, pension funds, and nonMMF investment funds, only the broad measure could be compiled. For the broad noncore measure, data prior to 2007: Q1 were estimated based on the growth rate of core liabilities.

\section{Turkey}

Data source(s): SRFs 2SR and 4SR reported to the IMF; sub-sectoral detail on MMFs, insurance corporations and pension funds were obtained in consultation with the Central Bank of Turkey.

Deviations: Separate data on non-MMF investment funds were not available but are included in the OFI sectoral balance sheet. As a result, the noncore measures may be overestimated. However, non-MMF investment funds represent only about 10 percent of total OFI liabilities, thus the overestimation is assumed to be small. Data on MMFs are available beginning 2007: Q4; insurance data are available beginning 2010: Q1; data on OFIs are available beginning 2008: Q1. Measures prior to the start of data availability do not include the respective sector.

\section{United Kingdom}

Data source(s): Bank of England statistical database; UK Office of National Statistics .

Deviations: Core liabilities contain OFI deposits; for both noncore measures MMF shares issued include any Bank of England holdings of MMF shares, ODC loan liabilities include loans from central government, OFI loans and securities issued include positions with all sectors. 


\section{United States}

Data source(s): SRFs 2SR and 4SR reported to the IMF; additional detail sourced from the US Federal Reserve's Flow of Funds database.

Deviations: The data compilation exercise for the United States served as our benchmark for other jurisdictions. All necessary detail was available to compile both the broad and narrow noncore measures. 


\section{Appendix III. Summary Tables}

Table 3. Broad noncore liabilities, percent of GDP

\begin{tabular}{|c|c|c|c|c|c|c|c|c|c|c|c|c|c|}
\hline & $2001 Q 4$ & $2002 Q 4$ & $2003 Q 4$ & $2004 Q 4$ & $2005 Q 4$ & 2006Q4 & $2007 Q 4$ & $2008 Q 4$ & $2009 Q 4$ & $2010 Q 4$ & $2011 Q 4$ & $2012 Q 4$ & $2013 Q 4$ \\
\hline Austria & 107.7 & 102.2 & 104.9 & 107.6 & 118.3 & 124.5 & 129.8 & 148.0 & 138.9 & 129.5 & 128.9 & 110.9 & 99.4 \\
\hline Belgium & 166.3 & 156.4 & 160.4 & 164.9 & 193.2 & 196.2 & 218.4 & 170.7 & 159.2 & 151.0 & 137.9 & 117.1 & 108.9 \\
\hline Cyprus & $\ldots$ & $\ldots$ & $\ldots$ & $\ldots$ & 189.1 & 227.5 & 267.4 & 331.4 & 423.4 & 357.7 & 331.2 & 305.4 & 156.9 \\
\hline Estonia & $\ldots$ & $\ldots$ & $\ldots$ & $\ldots$ & & $\ldots$ & $\ldots$ & 66.9 & 65.4 & 49.9 & 38.8 & 33.5 & 28.5 \\
\hline Euro Area & 99.3 & 97.9 & 99.4 & 104.1 & 115.6 & 121.2 & 128.4 & 130.9 & 128.4 & 123.7 & 118.1 & 110.1 & 97.3 \\
\hline Finland & 43.3 & 40.2 & 40.0 & 48.8 & 56.7 & 64.9 & 66.5 & 74.2 & 87.4 & 99.8 & 132.4 & 134.4 & 120.7 \\
\hline France & 98.0 & 99.2 & 99.0 & 108.6 & 127.2 & 143.4 & 158.7 & 160.5 & 151.2 & 152.8 & 142.9 & 137.4 & 128.6 \\
\hline Germany & 118.9 & 117.5 & 115.6 & 117.0 & 120.3 & 117.4 & 115.6 & 113.3 & 103.3 & 98.1 & 89.3 & 84.7 & 71.7 \\
\hline Greece & 17.6 & 22.3 & 24.8 & 27.8 & 28.8 & 35.1 & 46.8 & 49.5 & 48.5 & 55.6 & 46.0 & 42.1 & 40.7 \\
\hline Ireland & 403.3 & 410.2 & 452.4 & 550.5 & 677.3 & 797.1 & 874.3 & 954.5 & 970.7 & 878.8 & 686.9 & 610.4 & 557.1 \\
\hline Italy & 58.5 & 58.9 & 67.0 & 68.1 & 71.8 & 79.1 & 87.9 & 94.1 & 98.5 & 93.2 & 96.2 & 94.9 & 87.8 \\
\hline Japan & 118.5 & 119.6 & 123.4 & 124.9 & 132.4 & 125.6 & 122.1 & 115.9 & 114.6 & 111.5 & 109.3 & 116.4 & \\
\hline Korea & $\ldots$ & 65.9 & 60.4 & 55.7 & 57.1 & 65.9 & 74.1 & 82.4 & 78.7 & 69.4 & 72.0 & 75.5 & 78.6 \\
\hline Luxembourg & 2599.0 & 2482.1 & 2361.0 & 2276.7 & 2355.4 & 2160.9 & 2304.7 & 2544.4 & 2407.9 & 2028.7 & 2016.6 & 1677.9 & 1486.2 \\
\hline Malta & $\ldots$ & $\ldots$ & $\ldots$ & $\ldots$ & 310.1 & 359.0 & 435.3 & 455.3 & 425.7 & 427.3 & 439.9 & 439.3 & 410.8 \\
\hline Mexico & 4.0 & 4.0 & 3.7 & 2.7 & 2.4 & 2.3 & 2.1 & 2.5 & 2.3 & 2.4 & 2.5 & 2.5 & \\
\hline Netherlands & 177.7 & 184.5 & 190.4 & 208.9 & 229.2 & 251.5 & 269.0 & 234.1 & 254.2 & 255.8 & 262.3 & 248.8 & 222.5 \\
\hline Portugal & 90.8 & 93.9 & 103.7 & 100.5 & 96.9 & 106.6 & 118.6 & 119.7 & 131.6 & 134.3 & 136.5 & 130.7 & 107.3 \\
\hline Slovak Republic & $\cdots$ & $\ldots$ & $\ldots$ & $\ldots$ & $\cdots$ & 16.7 & 22.9 & 25.7 & 14.5 & 15.0 & 11.6 & 9.0 & 10.2 \\
\hline Slovenia & $\ldots$ & $\ldots$ & $\ldots$ & 19.9 & 32.4 & 37.3 & 48.6 & 51.9 & 51.0 & 50.9 & 42.4 & 32.4 & 23.1 \\
\hline South Africa & 25.7 & 26.9 & 26.5 & 29.2 & 31.6 & 37.6 & 43.2 & 49.9 & 48.2 & 46.3 & 41.6 & 43.3 & ... \\
\hline Spain & 99.4 & 78.4 & 89.3 & 94.7 & 108.2 & 105.6 & 116.8 & 124.6 & 132.6 & 132.4 & 129.0 & 103.5 & 84.4 \\
\hline Thailand & 36.0 & 24.7 & 20.4 & 20.7 & 20.0 & 22.2 & 23.3 & 25.7 & 25.9 & 34.5 & 45.3 & 35.7 & $\cdots$ \\
\hline Turkey & & 5.4 & 5.0 & 5.4 & 7.0 & 8.1 & 9.7 & 13.8 & 12.4 & 15.4 & 18.4 & 20.8 & 27.8 \\
\hline United Kingdom & 293.5 & 274.7 & 266.6 & 307.6 & 354.5 & 364.6 & 450.9 & 546.6 & 560.3 & 573.8 & 589.3 & 543.6 & 490.5 \\
\hline US & 126.0 & 130.0 & 131.3 & 133.2 & 137.8 & 150.4 & 162.8 & 165.1 & 147.7 & 128.8 & 122.4 & 115.1 & 109.8 \\
\hline
\end{tabular}

Source: IMF staff estimates.

Data available on quarterly basis. 
Table 4. Narrow noncore liabilities, percent of GDP

\begin{tabular}{|c|c|c|c|c|c|c|c|c|c|c|c|c|c|}
\hline & $2001 Q 4$ & $2002 Q 4$ & $2003 Q 4$ & 2004Q4 & 2005Q4 & 2006Q4 & 2007Q4 & $2008 Q 4$ & $2009 Q 4$ & $2010 Q 4$ & 2011Q4 & 2012Q4 & 2013Q4 \\
\hline Austria & 101.0 & 95.1 & 97.6 & 99.8 & 109.2 & 116.5 & 120.7 & 129.0 & 119.2 & 112.2 & 112.5 & 98.4 & 88.7 \\
\hline Belgium & 148.6 & 139.9 & 143.4 & 147.4 & 173.2 & 176.0 & 195.9 & 152.7 & 142.6 & 132.7 & 117.7 & 96.0 & 89.7 \\
\hline Cyprus & $\cdots$ & $\ldots$ & $\ldots$ & $\cdots$ & 187.6 & 226.1 & 266.0 & 330.1 & 422.0 & 357.0 & 330.7 & 305.2 & 156.8 \\
\hline Estonia & $\ldots$ & $\ldots$ & $\ldots$ & $\ldots$ & $\ldots$ & $\ldots$ & $\ldots$ & 66.9 & 65.4 & 49.9 & 38.8 & 33.5 & 28.5 \\
\hline Euro Area & 76.2 & 74.2 & 74.6 & 77.7 & 87.9 & 92.6 & 98.9 & 97.8 & 92.7 & 90.3 & 84.5 & 78.0 & 69.0 \\
\hline Finland & 38.5 & 34.6 & 35.3 & 43.9 & 51.6 & 59.0 & 61.4 & 67.4 & 83.6 & 97.4 & 129.6 & 132.6 & 118.7 \\
\hline France & 84.1 & 83.0 & 82.3 & 89.9 & 109.3 & 123.5 & 136.7 & 132.7 & 123.7 & 127.5 & 114.2 & 110.3 & 105.4 \\
\hline Germany & 87.9 & 87.5 & 85.7 & 86.8 & 91.1 & 91.1 & 90.9 & 87.0 & 76.4 & 75.4 & 68.8 & 66.7 & 55.7 \\
\hline Greece & 17.6 & 22.3 & 24.7 & 27.7 & 28.7 & 35.0 & 46.7 & 49.4 & 48.2 & 54.8 & 45.6 & 41.7 & 40.4 \\
\hline Ireland & 385.9 & 391.4 & 430.8 & 519.9 & 638.7 & 753.5 & 826.4 & 896.2 & 905.8 & 797.1 & 602.9 & 536.7 & 492.5 \\
\hline Italy & 50.6 & 50.7 & 57.6 & 58.4 & 60.8 & 67.1 & 74.9 & 76.5 & 76.0 & 71.2 & 69.0 & 62.3 & 57.3 \\
\hline Japan & 33.9 & 31.7 & 31.7 & 32.7 & 35.9 & 32.3 & 31.3 & 28.7 & 30.8 & 30.8 & 31.6 & 36.2 & .. \\
\hline Korea & $\ldots$ & 54.4 & 48.4 & 41.7 & 41.3 & 45.4 & 50.5 & 56.4 & 55.6 & 50.0 & 53.8 & 58.7 & 61.4 \\
\hline Luxembourg & 2565.1 & 2451.6 & 2331.3 & 2248.9 & 2329.7 & 2137.4 & 2280.9 & 2531.5 & 2385.4 & 2012.0 & 1999.3 & 1662.9 & 1461.5 \\
\hline Malta & $\ldots$ & $\ldots$ & $\ldots$ & $\ldots$ & 308.6 & 358.9 & 435.2 & 455.2 & 425.5 & 427.2 & 439.8 & 439.2 & 410.7 \\
\hline Mexico & $\cdots$ & $\ldots$ & $\cdots$ & $\cdots$ & $\cdots$ & $\cdots$ & $\cdots$ & $\cdots$ & $\ldots$ & $\cdots$ & $\cdots$ & $\cdots$ & $\ldots$ \\
\hline Netherlands & 149.6 & 156.4 & 161.4 & 177.5 & 195.1 & 214.6 & 229.4 & 200.0 & 215.6 & 217.3 & 226.5 & 216.4 & 193.4 \\
\hline Portugal & 82.7 & 86.3 & 94.1 & 92.1 & 91.0 & 100.2 & 111.5 & 110.5 & 119.1 & 108.8 & 93.2 & 83.7 & 65.2 \\
\hline Slovak Republic & $\ldots$ & $\ldots$ & $\ldots$ & $\ldots$ & $\ldots$ & 12.9 & 17.6 & 22.4 & 13.1 & 13.8 & 10.9 & 8.4 & 9.7 \\
\hline Slovenia & $\cdots$ & $\cdots$ & $\cdots$ & 16.8 & 22.3 & 31.9 & 47.5 & 50.3 & 48.1 & 46.9 & 39.9 & 30.7 & 22.1 \\
\hline South Africa & 22.1 & 18.2 & 17.3 & 18.0 & 19.7 & 26.1 & 31.0 & 35.9 & 33.1 & 30.1 & 29.4 & 32.5 & $\cdots$ \\
\hline Spain & 86.6 & 68.3 & 77.2 & 80.1 & 91.0 & 90.7 & 99.5 & 104.0 & 108.4 & 109.0 & 101.9 & 78.0 & 64.6 \\
\hline Thailand & $\cdots$ & $\ldots$ & $\ldots$ & $\ldots$ & $\cdots$ & $\cdots$ & $\cdots$ & $\cdots$ & $\ldots$ & $\cdots$ & $\ldots$ & $\ldots$ & $\cdots$ \\
\hline Turkey & $\ldots$ & 4.8 & 4.8 & 5.2 & 7.0 & 8.0 & 9.7 & 13.3 & 11.5 & 13.8 & 17.0 & 19.3 & 25.8 \\
\hline United Kingdom & 257.4 & 239.6 & 232.6 & 272.6 & 316.0 & 322.7 & 401.0 & 482.2 & 492.2 & 511.9 & 536.9 & 497.9 & 451.7 \\
\hline US & 68.1 & 70.8 & 72.7 & 77.0 & 81.0 & 90.0 & 97.5 & 97.0 & 92.7 & 85.2 & 81.6 & 76.5 & 73.0 \\
\hline
\end{tabular}

Source: IMF staff estimates.

Data available on quarterly basis. 
Table 5. Core liabilities, percent of GDP

\begin{tabular}{|c|c|c|c|c|c|c|c|c|c|c|c|c|c|}
\hline & 2001Q4 & $2002 Q 4$ & $2003 Q 4$ & 2004Q4 & 2005Q4 & $2006 Q 4$ & 2007Q4 & $2008 Q 4$ & $2009 Q 4$ & 2010Q4 & 2011Q4 & 2012Q4 & $2013 Q 4$ \\
\hline Austria & 84.8 & 83.4 & 86.2 & 84.9 & 87.8 & 86.7 & 89.7 & 96.1 & 95.6 & 92.5 & 92.9 & 91.6 & 91.6 \\
\hline Belgium & 76.2 & 77.5 & 82.1 & 85.6 & 87.0 & 88.8 & 88.7 & 90.1 & 95.0 & 96.6 & 96.1 & 100.8 & 103.8 \\
\hline Cyprus & $\ldots$ & $\ldots$ & $\ldots$ & $\ldots$ & 176.6 & 180.6 & 192.3 & 217.3 & 233.3 & 235.6 & 229.4 & 234.5 & 197.1 \\
\hline Estonia & $\ldots$ & $\ldots$ & $\ldots$ & $\ldots$ & $\ldots$ & $\ldots$ & $\ldots$ & 46.1 & 52.8 & 52.2 & 51.0 & 51.1 & 50.7 \\
\hline Euro Area & 74.8 & 74.6 & 75.5 & 76.4 & 77.9 & 78.7 & 82.0 & 87.7 & 91.3 & 90.6 & 91.2 & 94.4 & 95.6 \\
\hline Finland & 43.7 & 44.8 & 45.7 & 45.1 & 46.7 & 45.9 & 48.7 & 55.6 & 59.3 & 59.5 & 60.7 & 62.5 & 62.9 \\
\hline France & 61.8 & 60.8 & 63.6 & 63.9 & 64.7 & 63.3 & 63.1 & 65.8 & 68.4 & 70.3 & 74.1 & 77.7 & 79.1 \\
\hline Germany & 91.8 & 93.4 & 94.8 & 96.3 & 98.0 & 97.6 & 100.4 & 106.6 & 108.0 & 105.1 & 106.1 & 107.8 & 106.1 \\
\hline Greece & 84.1 & 77.2 & 70.5 & 72.0 & 79.9 & 81.4 & 87.2 & 98.6 & 99.6 & 96.7 & 86.2 & 86.4 & 92.4 \\
\hline Ireland & 59.6 & 58.1 & 59.7 & 64.3 & 69.3 & 75.3 & 74.4 & 83.5 & 101.9 & 96.5 & 85.5 & 86.3 & 88.0 \\
\hline Italy & 43.7 & 45.1 & 44.8 & 45.6 & 47.2 & 49.0 & 59.1 & 63.8 & 68.0 & 66.6 & 65.9 & 71.2 & 72.9 \\
\hline Japan & 176.9 & 177.7 & 178.9 & 179.5 & 179.1 & 175.6 & 176.1 & 186.3 & 195.6 & 197.1 & 205.7 & 212.6 & $\ldots$ \\
\hline Korea & $\ldots$ & 93.8 & 89.4 & 89.1 & 90.3 & 96.3 & 94.5 & 105.2 & 104.6 & 104.3 & 105.7 & 108.1 & 107.4 \\
\hline Luxembourg & 319.6 & 350.2 & 312.7 & 305.7 & 333.0 & 339.9 & 332.9 & 338.4 & 316.8 & 300.5 & 280.5 & 278.8 & 308.2 \\
\hline Malta & $\ldots$ & $\ldots$ & $\ldots$ & $\ldots$ & 128.4 & 132.6 & 144.8 & 138.9 & 138.3 & 136.0 & 144.3 & 144.8 & 151.0 \\
\hline Mexico & 5.0 & 4.8 & 5.0 & 4.9 & 5.0 & 5.0 & 5.2 & 5.6 & 6.0 & 6.2 & 6.1 & 6.5 & $\ldots$ \\
\hline Netherlands & 85.0 & 82.1 & 83.9 & 84.4 & 87.2 & 86.3 & 86.3 & 90.8 & 96.1 & 92.6 & 92.3 & 94.8 & 93.7 \\
\hline Portugal & 80.5 & 77.3 & 77.7 & 77.2 & 79.2 & 78.3 & 79.3 & 89.2 & 90.7 & 94.3 & 100.9 & 102.6 & 100.9 \\
\hline Slovak Republic & $\ldots$ & $\ldots$ & $\ldots$ & $\cdots$ & $\cdots$ & 46.3 & 46.7 & 52.9 & 51.6 & 51.7 & 52.4 & 54.6 & 56.1 \\
\hline Slovenia & $\ldots$ & $\ldots$ & $\ldots$ & 49.3 & 50.1 & 49.1 & 48.6 & 50.7 & 54.8 & 56.6 & 57.9 & 58.3 & 55.7 \\
\hline South Africa & 52.0 & 48.6 & 49.2 & 47.9 & 50.4 & 52.0 & 54.8 & 58.2 & 54.2 & 49.7 & 50.6 & 50.1 & ... \\
\hline Spain & 94.7 & 73.0 & 71.9 & 73.3 & 76.0 & 82.0 & 84.2 & 91.3 & 95.9 & 97.7 & 95.3 & 97.4 & 102.6 \\
\hline Thailand & 104.4 & 99.8 & 103.9 & 98.4 & 94.6 & 94.1 & 86.4 & 96.9 & 94.3 & 95.3 & 111.5 & 113.5 & $\cdots$ \\
\hline Turkey & $\ldots$ & 31.5 & 28.5 & 28.0 & 34.1 & 35.5 & 35.7 & 42.6 & 43.9 & 44.7 & 45.0 & 46.1 & 50.5 \\
\hline United Kingdom & 91.9 & 90.1 & 90.5 & 95.0 & 101.6 & 109.3 & 118.2 & 138.1 & 141.8 & 145.7 & 139.3 & 136.3 & 133.9 \\
\hline US & 42.4 & 43.6 & 45.3 & 47.0 & 48.4 & 49.7 & 50.8 & 52.0 & 56.6 & 55.5 & 58.6 & 60.2 & 60.3 \\
\hline
\end{tabular}

Source: IMF staff estimates.

Data available on quarterly basis. 
Table 6. Broad noncore liabilities (USD billion)

\begin{tabular}{|c|c|c|c|c|c|c|c|c|c|c|c|c|c|}
\hline & 2001Q4 & $2002 Q 4$ & $2003 Q 4$ & 2004Q4 & 2005Q4 & 2006Q4 & 2007Q4 & $2008 Q 4$ & 2009Q4 & $2010 Q 4$ & 2011Q4 & 2012Q4 & 2013Q4 \\
\hline Austria & 208.8 & 238.6 & 300.1 & 349.5 & 353.7 & 441.9 & 539.3 & 580.8 & 575.0 & 517.7 & 508.4 & 460.1 & 440.3 \\
\hline Belgium & 401.3 & 464.0 & 590.2 & 687.1 & 739.7 & 878.1 & $1,131.1$ & 849.2 & 823.6 & 766.7 & 695.7 & 608.8 & 603.1 \\
\hline Cyprus & $\ldots$ & $\ldots$ & $\ldots$ & $\ldots$ & 31.0 & 44.7 & 64.1 & 80.1 & 102.7 & 84.6 & 76.8 & 69.9 & 34.7 \\
\hline Estonia & $\ldots$ & $\ldots$ & $\ldots$ & $\ldots$ & $\ldots$ & $\ldots$ & $\ldots$ & 14.9 & 13.4 & 10.4 & 8.6 & 8.0 & 7.6 \\
\hline Euro Area & $6,523.9$ & $7,829.2$ & $9,862.8$ & $11,545.5$ & $11,649.4$ & $14,357.3$ & $17,668.3$ & $17,099.7$ & $17,036.8$ & $15,775.8$ & $14,817.9$ & $14,088.0$ & $13,198.8$ \\
\hline Finland & 56.0 & 63.7 & 77.5 & 107.2 & 111.9 & 151.6 & 186.5 & 196.1 & 224.3 & 255.1 & 338.2 & 349.6 & 332.7 \\
\hline France & $1,345.2$ & $1,652.0$ & $2,057.8$ & $2,518.7$ & $2,673.2$ & $3,549.9$ & $4,554.1$ & $4,383.9$ & $4,213.9$ & $4,093.5$ & $3,812.9$ & $3,772.3$ & $3,748.4$ \\
\hline Germany & $2,295.5$ & $2,697.9$ & $3,212.7$ & $3,556.4$ & $3,249.9$ & $3,711.0$ & $4,202.9$ & $3,882.9$ & $3,639.1$ & $3,386.3$ & $3,071.9$ & $3,015.1$ & $2,759.3$ \\
\hline Greece & 23.9 & 38.2 & 56.1 & 72.6 & 68.6 & 100.1 & 156.0 & 161.1 & 167.5 & 162.1 & 121.4 & 104.8 & 100.5 \\
\hline Ireland & 440.9 & 598.4 & 860.2 & $1,177.7$ & $1,375.7$ & $1,917.5$ & $2,481.2$ & $2,343.0$ & $2,193.6$ & $1,790.2$ & $1,444.1$ & $1,308.7$ & $1,231.1$ \\
\hline Italy & 697.3 & 858.9 & $1,211.1$ & $1,377.3$ & $1,309.9$ & $1,662.0$ & $2,117.2$ & $2,137.4$ & $2,256.0$ & $2,040.9$ & $2,055.6$ & $2,037.8$ & $1,967.0$ \\
\hline Japan & $4,757.3$ & $5,295.0$ & $6,054.1$ & $6,401.1$ & $5,934.9$ & $5,642.9$ & $5,858.2$ & $6,530.5$ & $6,119.1$ & $6,917.4$ & $7,043.1$ & $6,595.2$ & $\ldots$ \\
\hline Korea & $\cdots$ & 447.4 & 440.8 & 494.0 & 552.0 & 726.8 & 885.0 & 746.9 & 825.3 & 817.9 & 879.5 & $1,012.0$ & $1,111.7$ \\
\hline Luxembourg & 559.3 & 644.2 & 826.6 & 901.6 & 891.6 & $1,038.9$ & $1,310.4$ & $1,352.5$ & $1,287.9$ & $1,145.0$ & $1,168.8$ & $1,027.9$ & 993.7 \\
\hline Malta & $\ldots$ & $\ldots$ & $\ldots$ & $\ldots$ & 18.6 & 24.9 & 35.7 & 38.0 & 37.2 & 37.9 & 38.1 & 40.1 & 41.0 \\
\hline Mexico & 120.4 & 114.4 & 105.9 & 87.3 & 88.3 & 94.1 & 94.9 & 89.8 & 91.0 & 109.3 & 113.2 & 125.7 & $\ldots$ \\
\hline Netherlands & 733.3 & 930.1 & $1,180.5$ & $1,445.3$ & $1,455.8$ & $1,872.5$ & $2,359.4$ & $1,998.8$ & $2,160.5$ & $2,109.4$ & $2,105.5$ & $2,032.3$ & $1,919.6$ \\
\hline Portugal & 115.1 & 144.1 & 196.6 & 213.1 & 186.3 & 240.7 & 308.7 & 295.8 & 334.8 & 323.1 & 310.6 & 287.1 & 257.4 \\
\hline Slovak Republic & $\ldots$ & $\ldots$ & $\ldots$ & $\ldots$ & $\ldots$ & 13.1 & 21.9 & 24.0 & 13.4 & 13.6 & 10.7 & 8.6 & 10.4 \\
\hline Slovenia & $\ldots$ & $\ldots$ & $\ldots$ & 7.7 & 11.4 & 16.0 & 25.4 & 26.7 & 26.1 & 24.5 & 19.8 & 14.9 & 11.4 \\
\hline South Africa & 22.5 & 38.1 & 52.4 & 76.9 & 82.6 & 100.9 & 135.5 & 124.3 & 163.3 & 195.7 & 156.3 & 165.9 & $\ldots$ \\
\hline Spain & 487.8 & 633.2 & 931.9 & $1,140.9$ & $1,235.3$ & $1,450.0$ & $1,899.5$ & $1,943.1$ & $2,064.0$ & $1,927.0$ & $1,794.3$ & $1,435.3$ & $1,221.2$ \\
\hline Thailand & 43.1 & 32.6 & 32.1 & 37.0 & 37.2 & 50.4 & 71.9 & 65.4 & 74.5 & 118.9 & 141.2 & 138.3 & $\ldots$ \\
\hline Turkey & $\ldots$ & $\ldots$ & 34.6 & 43.9 & 65.6 & 92.1 & 99.9 & 198.3 & 189.1 & 280.5 & 478.7 & 542.1 & 967.9 \\
\hline United Kingdom & $4,462.7$ & $4,935.9$ & $5,659.6$ & $7,382.4$ & $8,027.8$ & $9,982.5$ & $13,102.9$ & $11,661.4$ & $13,127.1$ & $13,575.8$ & $14,306.3$ & $13,999.6$ & $13,387.5$ \\
\hline US & $13,488.0$ & $14,438.2$ & $15,520.4$ & $16,732.7$ & $18,444.6$ & $21,161.0$ & $23,909.5$ & $24,014.2$ & $21,505.9$ & $19,619.9$ & $19,362.2$ & $18,907.5$ & $18,756.0$ \\
\hline
\end{tabular}

Source: IMF staff estimates.

Data available on quarterly basis. 
Table 7. Narrow noncore liabilities (USD billion)

\begin{tabular}{|c|c|c|c|c|c|c|c|c|c|c|c|c|c|}
\hline & 2001Q4 & 2002Q4 & 2003Q4 & 2004Q4 & 2005Q4 & 2006Q4 & 2007Q4 & $2008 Q 4$ & 2009Q4 & 2010Q4 & 2011Q4 & 2012Q4 & 2013Q4 \\
\hline Austria & 195.6 & 222.0 & 279.1 & 324.1 & 326.7 & 413.5 & 501.3 & 506.2 & 493.5 & 448.3 & 443.5 & 408.5 & 393.1 \\
\hline Belgium & 358.4 & 415.0 & 527.5 & 614.2 & 663.3 & 787.7 & $1,014.3$ & 759.8 & 737.5 & 674.0 & 594.2 & 499.3 & 496.4 \\
\hline Cyprus & $\ldots$ & $\cdots$ & $\cdots$ & $\cdots$ & 30.7 & 44.4 & 63.8 & 79.8 & 102.3 & 84.4 & 76.7 & 69.9 & 34.7 \\
\hline Estonia & $\ldots$ & $\ldots$ & $\ldots$ & $\ldots$ & $\ldots$ & $\ldots$ & $\ldots$ & 14.9 & 13.4 & 10.4 & 8.6 & 8.0 & 7.6 \\
\hline Euro Area & $5,002.3$ & $5,938.3$ & $7,405.7$ & $8,613.1$ & $8,852.1$ & $10,964.8$ & $13,603.3$ & $12,779.0$ & $12,300.4$ & $11,518.5$ & $10,602.5$ & $9,974.2$ & $9,354.3$ \\
\hline Finland & 49.8 & 54.7 & 68.4 & 96.4 & 101.8 & 137.8 & 172.1 & 178.3 & 214.6 & 249.1 & 331.1 & 344.8 & 327.2 \\
\hline France & $1,154.0$ & 1,382.1 & $1,710.7$ & $2,084.6$ & $2,296.8$ & $3,057.1$ & $3,923.1$ & $3,622.9$ & $3,449.0$ & $3,415.7$ & $3,048.0$ & $3,027.0$ & $3,072.3$ \\
\hline Germany & 1,698.0 & $2,008.3$ & $2,381.3$ & $2,638.3$ & $2,461.5$ & $2,880.8$ & $3,304.1$ & $2,983.2$ & $2,691.0$ & $2,603.0$ & $2,366.6$ & $2,374.1$ & $2,143.7$ \\
\hline Greece & 23.9 & 38.1 & 56.0 & 72.4 & 68.4 & 100.0 & 155.9 & 160.7 & 166.4 & 159.7 & 120.5 & 103.9 & 99.8 \\
\hline Ireland & 421.9 & 571.0 & 819.2 & $1,112.2$ & $1,297.1$ & $1,812.7$ & $2,345.1$ & $2,199.9$ & $2,046.9$ & $1,623.9$ & $1,267.6$ & $1,150.8$ & $1,088.3$ \\
\hline Italy & 603.3 & 738.9 & $1,041.1$ & $1,180.8$ & $1,109.5$ & $1,410.1$ & $1,804.1$ & $1,736.6$ & $1,739.4$ & $1,560.2$ & $1,474.4$ & $1,337.8$ & $1,283.7$ \\
\hline Japan & $1,361.4$ & $1,405.3$ & $1,557.7$ & $1,677.0$ & $1,609.5$ & $1,452.4$ & $1,502.4$ & $1,618.2$ & $1,642.5$ & $1,910.8$ & $2,034.0$ & $2,050.3$ & .. \\
\hline Korea & $\ldots$ & 369.5 & 353.2 & 370.4 & 399.5 & 500.8 & 602.5 & 511.5 & 583.1 & 588.9 & 657.2 & 786.6 & 868.9 \\
\hline Luxembourg & 551.9 & 636.3 & 816.2 & 890.7 & 881.9 & $1,027.6$ & $1,296.9$ & $1,345.7$ & $1,275.9$ & $1,135.6$ & $1,158.8$ & $1,018.7$ & 977.2 \\
\hline Malta & $\ldots$ & $\ldots$ & $\ldots$ & $\cdots$ & 18.5 & 24.8 & 35.7 & 38.0 & 37.2 & 37.9 & 38.1 & 40.1 & 41.0 \\
\hline Mexico & $\cdots$ & $\cdot$ & $\cdots$ & $\cdots$ & $\cdots$ & $\cdots$ & $\cdots$ & $\cdots$ & $\cdots$ & $\cdots$ & $\cdots$ & $\cdots$ & $\cdots$ \\
\hline Netherlands & 617.4 & 788.5 & $1,000.9$ & $1,228.4$ & $1,238.8$ & $1,597.9$ & $2,011.8$ & $1,707.0$ & $1,832.3$ & $1,791.7$ & $1,818.6$ & $1,767.7$ & $1,668.1$ \\
\hline Portugal & 104.8 & 132.4 & 178.3 & 195.3 & 175.0 & 226.1 & 290.2 & 273.2 & 303.0 & 261.9 & 212.2 & 183.9 & 156.3 \\
\hline Slovak Republic & $\ldots$ & $\ldots$ & $\ldots$ & $\ldots$ & $\cdots$ & 10.1 & 16.8 & 20.9 & 12.1 & 12.5 & 10.1 & 8.1 & 9.8 \\
\hline Slovenia & $\ldots$ & $\ldots$ & $\ldots$ & 6.5 & 7.8 & 13.7 & 24.8 & 25.8 & 24.6 & 22.6 & 18.6 & 14.1 & 10.9 \\
\hline South Africa & 19.4 & 25.7 & 34.3 & 47.3 & 51.4 & 69.9 & 97.1 & 89.4 & 112.0 & 127.3 & 110.2 & 124.7 & $\cdots$ \\
\hline Spain & 424.9 & 551.4 & 805.6 & 965.4 & $1,039.4$ & $1,246.3$ & $1,618.7$ & $1,622.4$ & $1,687.3$ & $1,587.7$ & $1,417.2$ & $1,081.2$ & 934.5 \\
\hline Tha & $\cdots$ & $\cdots$ & $\cdots$ & $\cdots$ & $\cdots$ & $\cdots$ & $\cdots$ & $\cdots$ & $\ldots$ & $\cdots$ & $\cdots$ & $\cdots$ & $\cdots$ \\
\hline Turkey & $\cdots$ & 32.2 & 33.2 & 42.2 & 65.4 & 91.8 & 99.5 & 191.1 & 175.7 & 252.6 & 441.4 & 501.0 & 899.6 \\
\hline United Kingdom & $3,913.0$ & $4,304.8$ & $4,938.4$ & $6,542.0$ & $7,155.0$ & $8,834.7$ & $11,653.2$ & $10,287.3$ & $11,532.0$ & $12,110.8$ & $13,033.5$ & $12,823.4$ & $12,328.1$ \\
\hline US & $7,283.5$ & $7,863.0$ & $8,591.6$ & $9,670.7$ & $10,840.5$ & $12,657.4$ & $14,320.4$ & $14,112.7$ & $13,500.2$ & $12,981.6$ & $12,907.1$ & $12,559.0$ & $12,480.7$ \\
\hline
\end{tabular}

Source: IMF staff estimates.

Data available on quarterly basis. 
Table 8. Core liabilities (USD billion)

\begin{tabular}{|c|c|c|c|c|c|c|c|c|c|c|c|c|c|}
\hline & 2001Q4 & $2002 Q 4$ & $2003 Q 4$ & $2004 Q 4$ & $2005 Q 4$ & $2006 Q 4$ & 2007 Q4 & $2008 Q 4$ & 2009 Q4 & $2010 Q 4$ & $2011 Q 4$ & $2012 Q 4$ & $2013 Q 4$ \\
\hline Austria & 164.3 & 194.7 & 246.6 & 275.8 & 262.6 & 307.9 & 372.8 & 377.1 & 395.8 & 369.7 & 366.3 & 380.0 & 405.5 \\
\hline Belgium & 183.9 & 229.9 & 302.0 & 356.6 & 333.0 & 397.3 & 459.3 & 448.3 & 491.2 & 490.5 & 484.9 & 524.2 & 574.8 \\
\hline Cyprus & $\ldots$ & $\ldots$ & $\ldots$ & $\ldots$ & 28.9 & 35.5 & 46.1 & 52.5 & 56.6 & 55.7 & 53.2 & 53.7 & 43.6 \\
\hline Estonia & $\ldots$ & $\ldots$ & $\ldots$ & $\ldots$ & $\ldots$ & $\ldots$ & $\ldots$ & 10.3 & 10.8 & 10.8 & 11.3 & 12.3 & 13.4 \\
\hline Euro Area & $4,912.0$ & $5,966.2$ & $7,495.1$ & $8,470.4$ & $7,844.7$ & $9,319.7$ & $11,278.9$ & $11,454.0$ & $12,109.2$ & $11,557.5$ & $11,440.7$ & $12,074.1$ & $12,970.6$ \\
\hline Finland & 56.6 & 71.0 & 88.7 & 98.9 & 92.2 & 107.2 & 136.4 & 147.0 & 152.2 & 152.1 & 155.1 & 162.5 & 173.3 \\
\hline France & 848.7 & $1,012.6$ & $1,321.5$ & $1,481.9$ & $1,359.9$ & $1,567.3$ & $1,809.2$ & $1,797.5$ & $1,906.9$ & $1,883.7$ & $1,977.7$ & $2,133.3$ & $2,306.1$ \\
\hline Germany & $1,772.9$ & $2,145.1$ & $2,636.7$ & 2,927.1 & $2,648.2$ & $3,084.0$ & $3,648.8$ & $3,652.7$ & $3,804.0$ & $3,629.3$ & $3,649.5$ & $3,836.6$ & $4,081.6$ \\
\hline Greece & 114.1 & 132.1 & 159.6 & 188.0 & 190.3 & 232.4 & 291.1 & 320.9 & 344.2 & 282.1 & 227.4 & 215.1 & 228.4 \\
\hline Ireland & 65.1 & 84.7 & 113.4 & 137.6 & 140.8 & 181.1 & 211.2 & 204.9 & 230.2 & 196.6 & 179.7 & 185.0 & 194.4 \\
\hline Italy & 520.7 & 657.1 & 810.0 & 922.9 & 861.1 & $1,029.8$ & $1,424.0$ & $1,449.0$ & $1,556.4$ & $1,459.8$ & $1,409.2$ & $1,528.7$ & $1,634.6$ \\
\hline Japan & $7,099.8$ & 637.0 & 652.0 & 790.7 & 873.2 & $1,062.9$ & $1,128.8$ & 953.2 & $1,097.3$ & $1,228.9$ & $1,290.7$ & $1,447.7$ & $1,519.4$ \\
\hline Korea & $\cdots$ & 637.0 & 652.0 & 790.7 & 873.2 & $1,062.9$ & $1,128.8$ & 953.2 & $1,097.3$ & $1,228.9$ & $1,290.7$ & $1,447.7$ & $1,519.4$ \\
\hline Luxembourg & 68.8 & 90.9 & 109.5 & 121.1 & 126.0 & 163.4 & 189.3 & 179.9 & 169.4 & 169.6 & 162.6 & 170.8 & 206.1 \\
\hline Malta & $\ldots$ & $\ldots$ & $\cdots$ & $\cdots$ & 7.7 & 9.2 & 11.9 & 11.6 & 12.1 & 12.1 & 12.5 & 13.2 & 15.1 \\
\hline Mexico & 150.9 & 139.6 & 143.5 & 159.3 & 185.6 & 202.0 & 231.8 & 203.1 & 235.4 & 281.1 & 272.1 & 322.6 & $\cdots$ \\
\hline Netherlan & 350.6 & 414.0 & 520.1 & 584.0 & 553.7 & 642.2 & 756.9 & 775.1 & 817.2 & 763.6 & 740.8 & 774.7 & 808.0 \\
\hline Portugal & 102.0 & 118.6 & 147.3 & 163.7 & 152.3 & 176.8 & 206.5 & 220.6 & 230.7 & 227.0 & 229.7 & 225.3 & 242.0 \\
\hline Slovak Republic & $\ldots$ & $\ldots$ & $\cdots$ & $\cdots$ & $\cdots$ & 36.3 & 44.7 & 49.5 & 47.6 & 46.8 & 48.5 & 52.2 & 56.9 \\
\hline Slovenia & $\cdots$ & $\ldots$ & $\cdots$ & 19.0 & 17.6 & 21.0 & 25.4 & 26.1 & 28.0 & 27.3 & 27.0 & 26.8 & 27.5 \\
\hline South Africa & 45.6 & 68.7 & 97.3 & 126.2 & 131.5 & 139.6 & 171.8 & 144.9 & 183.7 & 210.1 & 189.9 & 191.8 & $\cdots$ \\
\hline Spain & 464.4 & 590.0 & 750.8 & 883.4 & 867.3 & $1,125.8$ & $1,369.3$ & $1,423.9$ & $1,493.7$ & $1,423.0$ & $1,325.3$ & $1,350.8$ & $1,484.9$ \\
\hline Thailand & 124.8 & 131.8 & 163.9 & 175.7 & 175.7 & 213.7 & 266.4 & 246.5 & 271.7 & 328.1 & 347.4 & 440.0 & \\
\hline Turkey & $\ldots$ & 210.1 & 196.6 & 228.2 & 317.9 & 404.5 & 366.6 & 611.9 & 668.1 & 815.2 & $1,170.9$ & $1,199.8$ & $1,760.2$ \\
\hline United Kingdom & $1,396.6$ & $1,618.7$ & $1,920.9$ & $2,278.9$ & $2,300.2$ & $2,993.6$ & $3,433.8$ & $2,945.8$ & $3,321.3$ & $3,448.1$ & $3,381.7$ & $3,509.7$ & $3,655.2$ \\
\hline US & $4,541.5$ & $4,837.8$ & $5,352.6$ & $5,903.0$ & $6,480.3$ & $6,993.1$ & $7,465.8$ & $7,566.3$ & $8,236.7$ & $8,458.7$ & $9,263.0$ & $9,882.6$ & $10,303.1$ \\
\hline
\end{tabular}

Source: IMF staff estimates.

Data available on quarterly basis. 


\section{References}

Adrian, Tobias and Adam B. Ashcraft, 2012, "Shadow Banking: A Review of the Literature," Federal Reserve Bank of New York Staff Report No. 580 (New York: Federal Reserve Bank October 2012.

Adrian, Tobias, and Hyun Song Shin, 2009, "The Shadow Banking System: Implications for Financial Regulation,” Banque de France Financial Stability Review 13:1-10.

Adrian, Tobias, and Hyun Song Shin, 2012, "Which Financial Frictions? Parsing the Evidence from the Financial Crisis of 2007-9," NBER Working Papers No. 18335 (Cambridge, Massachusetts: National Bureau of Economic Research).

Bakk-Simon, Klara, Stefano Borgioli, Celestino Giron, Hannah Hempell, Angela Maddaloni, Fabio Recine, and Simonetta Rosati, 2012, "Shadow Banking in the Euro Area: An overview," European Central Bank, Occasional Paper Series No. 133.

Chen, Sally, Philip Liu, Andrea Maechler, Chris Marsh, Sergejs Saksonovs, and Hyun Song Shin, 2012, "Exploring the Dynamics of Global Liquidity," IMF Working Paper No. 12/246, International Monetary Fund.

Claessens, Stijn, Zoltan Pozsar, Lev Ratnovski, and Manmohan Singh, 2012, "Shadow Banking: Economics and Policy,” IMF Staff Discussion Note 12/12, International Monetary Fund.

Errico, Luca, Artak Harutyunyan, Elena Loukoianova, Richard Walton, Yevgeniya Korniyenko, Goran Amidžić, Hanan AbuShanab, Hyun Song Shin, 2014, "Mapping the Shadow Banking System Through a Global Flow of Funds Analysis," IMF Working Paper No. 14/10, International Monetary Fund.

Financial Stability Board, 2011, "Shadow Banking: Strengthening Oversight and Regulation," http://www.financialstabilityboard.org/publications/r_111027a.pdf.

_ 2012, "Global Shadow Banking Monitoring Report 2012" http:/www.financialstabilityboard.org/publications/r 121118c.pdf.

_ 2013, "Strengthening Oversight and Regulation of Shadow Banking: An Overview of Policy Recommendations," August 2013 http://www.financialstabilityboard.org/publications/r 130829a.pdf.

- 2014, "Global Shadow Banking Monitoring Report 2014” http://www.financialstabilityboard.org/publications/r_141030.pdf.

Gorton, Gary, and Andrew Metrick, 2012, "Securitized Banking and the Run on Repo," Journal of Financial Economics, Vol. 104, No. 3, pp. 425-51.

International Monetary Fund, 2014, "Shadow Banking Around the Globe: How Large, and How Risky?" Chapter 2 in Global Financial Stability Report, October (Washington). 
— 2000, "Monetary and Financial Statistics Manual," International Monetary Fund, http://www.imf.org/external/pubs/ft/mfs/manual/index.htm.

— , forthcoming, draft "Monetary and Financial Statistics Manual and Compilation Guide," International Monetary Fund, http://www.imf.org/external/pubs/ft/mfs/manual/index.htm.

Hahm, Joon-Ho, Hyun Song Shin and Kwanho Shin, 2011a, "Noncore Bank Liabilities and Financial Vulnerability," NBER working paper 18428, (Cambridge, Massachusetts: National Bureau of Economic Research).

Pozsar, Zoltan, 2008, “The Rise and Fall of the Shadow Banking System," Moody's Economy.com - Regional Financial Review, July, at www.economy.com/sbs.

Pozsar, Zoltan, Tobias Adrian, Adam Ashcraft, and Hayley Boesky, 2010, "Shadow Banking," FRBNY Staff Report No. 458 (New York: Federal Reserve Bank of New York).

Ricks, Morgan, 2010, "Shadow Banking and Financial Regulation," Columbia Law and Economics, Working Paper No. 370.

Satoru, Hagino and Cavieres, Liliana, 2012, "OECD financial statistics for measuring the structure and size of the shadow banking system," IFC Bulletin No. 36.

Shiller, Robert J., 2012, "Finance and the Good Society," (Princeton, New Jersey: Princeton University Press).

Shin, Hyun Song, 2012, "Global Banking Glut and Loan Risk Premium," Mundell-Fleming Lecture, IMF Economic Review 60 (2), pp. 155-192.

Shin, Hyun Song and Kwanho Shin, 2010, "Procyclicality and Monetary Aggregates" NBER Working Paper No. 16836, (Cambridge, Massachusetts: National Bureau of Economic Research).

Schwarcz, Steven L., 2012, "Regulating Shadow Banking," Review of Banking and Financial Law, Vol. 31.

Schularick, Moritz and Alan M. Taylor, 2012, "Credit Booms Gone Bust: Monetary Policy, Leverage Cycles and Financial Crises, 1870-2008”. American Economic Review, American Economic Association, Vol. 102(2), pages 1029-61.

SNA 2008 - System of National Accounts 2008 (New York: a publication of the Commission of the European Communities, International Monetary Fund, Organization for Economic Cooperation and Development, United Nations, and the World Bank, 2009), http://unstats.un.org/unsd/nationalaccount/docs/SNA2008.pdf. 